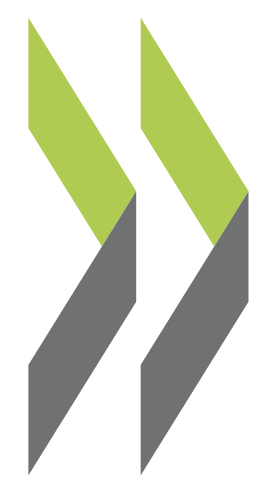

OECD Economics Department Working Papers No. 1633

\title{
Walking the tightrope: avoiding a lockdown while containing the virus
}

\section{Balázs Égert,}

\section{Yvan Guillemette,}

Fabrice Murtin,

David Turner 


\section{ECONOMICS DEPARTMENT}

\section{WALKING THE TIGHTROPE: AVOIDING A LOCKDOWN WHILE CONTAINING THE VIRUS}

\section{ECONOMICS DEPARTMENT WORKING PAPERS No. 1633}

By: Balázs Égert, Yvan Guillemette, Fabrice Murtin and David Turner

OECD Working Papers should not be reported as representing the official views of the OECD or its member countries. The opinions expressed and arguments employed are those of the author(s).

Authorised for publication by Luiz de Mello, Director, Policy Studies Branch, Economics Department.

All Economics Department Working Papers are available at www.oecd.org/eco/workingpapers.

JT03469658 
OECD Working Papers should not be reported as representing the official views of the OECD or of its member countries. The opinions expressed and arguments employed are those of the author(s).

Working Papers describe preliminary results or research in progress by the author(s) and are published to stimulate discussion on a broad range of issues on which the OECD works.

Comments on Working Papers are welcomed, and may be sent to OECD Economics Department, 2 rue André Pascal, 75775 Paris Cedex 16, France, or by e-mail to eco.contact@oecd.org.

All Economics Department Working Papers are available at www.oecd.org/eco/workingpapers

This document and any map included herein are without prejudice to the status of or sovereignty over any territory, to the delimitation of international frontiers and boundaries and to the name of any territory, city or area.

The statistical data for Israel are supplied by and under the responsibility of the relevant Israeli authorities. The use of such data by the OECD is without prejudice to the status of the Golan Heights, East Jerusalem and Israeli settlements in the West Bank under the terms of international law.

\section{(C) OECD (2020)}

You can copy, download or print OECD content for your own use, and you can include excerpts from OECD publications, databases and multimedia products in your own documents, presentations, blogs, websites and teaching materials, provided that suitable acknowledgment of OECD as source and copyright owner is given. Requests for commercial use and translation rights should be submitted to PubRights@oecd.org. 


\section{ABSTRACT/RESUMÉ \\ Walking the tightrope: avoiding a lockdown while containing the virus}

Empirical work described in this paper explains the daily evolution of the reproduction rate, $R$, and mobility for a large sample of countries, in terms of containment and public health policies. This is with a view to providing insight into the appropriate policy stance as countries prepare for a potentially protracted period characterised by new infection waves. While a comprehensive package of containment measures may be necessary when the virus is widespread and can have a large effect on reducing $R$, they also have effect on mobility and, by extension, economic activity. A wide-ranging package of public health policies - with an emphasis on comprehensive testing, tracing and isolation, but also including mask-wearing and policies directed at vulnerable groups, especially those in care homes - offer the best approach to avoiding a full lockdown while containing the spread of the virus. Such policies may, however, need to be complemented by selective containment measures (such as restricting large public events and international travel or localised lockdowns) both to contain local outbreaks and because implementing some of the recommended public health policies may be difficult to achieve or have unacceptable social costs.

Keywords: Covid-19, lockdown, non-pharmaceutical interventions, mobility

JEL codes: C50, $\mathrm{H} 10, \mathrm{H} 12, \mathrm{I} 18$.

\section{Marcher sur la corde raide: éviter de verrouiller l'économie tout en maitrisant le virus}

Les travaux empiriques décrits dans cet article expliquent l'évolution quotidienne du taux de reproduction, $\mathrm{R}$, et de la mobilité pour un large échantillon de pays, en fonction des politiques de restriction du mouvement et de santé publique. Ceci dans le but de donner un aperçu de la politique appropriée alors que les pays se préparent à une période potentiellement prolongée caractérisée par de nouvelles vagues d'infection. Si un ensemble complet de mesures de restriction peut être nécessaire lorsque le virus est répandu et peut avoir un effet important sur la réduction de $\mathrm{R}$, ils ont également un effet sur la mobilité et, par extension, l'activité économique. Un vaste ensemble de politiques de santé publique - avec un accent sur les tests à grande échelle, le traçage et l'isolement, mais aussi le port du masque et les politiques destinées aux groupes vulnérables, en particulier ceux des maisons de retraite - offrent la meilleure approche pour éviter un verrouillage complet de l'économie tout en contenir la propagation du virus. Ces politiques peuvent cependant devoir être complétées par des mesures de restriction de mouvement sélectives (telles que la restriction des grands événements publics et des voyages internationaux ou des confinements localisés) à la fois pour contenir les flambées locales et parce que la mise en œuvre de certaines des politiques de santé publique recommandées peut être difficile ou engendrer des coûts sociaux inacceptables.

Mots-clés: Covid-19, confinement, interventions non pharmaceutiques, mobilité

Codes JEL : C50, $\mathrm{H} 10, \mathrm{H} 12, \mathrm{I} 18$ 


\section{Table of contents}

WALKING THE TIGHTROPE: AVOIDING A LOCKDOWN WHILE CONTAINING THE VIRUS

1. Introduction and main findings 6

2.1. The reproduction rate $\quad 8$

2.2. Containment policies and mobility 9

2.3. Test, trace and isolation policies 12

2.4. Shielding the elderly 14

2.5. Mask-wearing 15

2.6. Induced cautious behaviour and towards achieving herd immunity 16

3. Empirical evidence on the impact of policies on the reproduction rate and mobility 18

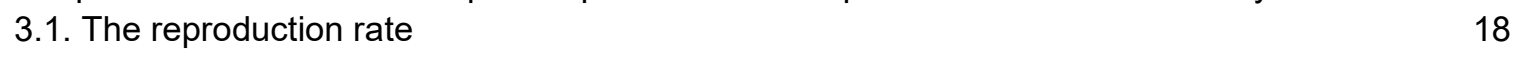

4.1. Which lockdown policies should stay in place longest? 27

References 28

Annex A. Estimation of effective reproduction number $(R) \quad 31$

Annex B. Auxiliary regression results 33

\section{Tables}

Table 1. Scoring of different stringency levels of containment policies according to the Oxford Covid-19 Government Response Tracker

Table 2. Scoring of the Oxford testing and contract tracing policy variables 13

$\begin{array}{lr}\text { Table 3. Scoring of additional public health measures } & 15\end{array}$

Table 4. OECD countries scoring highly on specific policies $\quad 17$

Table 5. The drivers of the reproduction rate $\quad 22$

$\begin{array}{ll}\text { Table } 6 \text {. The drivers of mobility } & 24\end{array}$

Table 7. Scenario assumptions and outcomes for R and mobility 26

Table B.1. The drivers of the reproduction rate, OECD containment measures 33

Table B.2. The drivers of mobility, OECD containment measures $\quad 34$

\section{Figures}

Figure 1. Median and interquartile range for effective reproduction rate $(R)$

Figure 2. Link between mobility and GDP forecast revisions at a quarterly frequency for 2020 Q1 and Q2 10

Figure 3. Percentage of countries at different stringency levels for containment policies according to the Oxford Covid-19 Government Response Tracker

Figure 4. Percentage of countries at different stringency levels for testing and contact tracing policies according to the Oxford Covid-19 Government Response Tracker 
Figure 5. Effect of containment policies and public health policies on (logged) $R$

\section{Boxes}

Box 1. Policy option to reduce exposure to the COVID-19 virus 


\title{
WALKING THE TIGHTROPE: AVOIDING A LOCKDOWN WHILE CONTAINING THE
} VIRUS

\author{
Balázs Égert, Yvan Guillemette, Fabrice Murtin and David Turner ${ }^{1}$
}

\section{Introduction and main findings}

1. In most OECD countries, a combination of public health and containment measures, often involving a shutdown of major parts of the economy, was successful in reducing the spread of the new coronavirus (SARS-Cov-2) and associated diseases (Covid-19, used henceforth) in the first half of 2020. Having lifted many restrictions, the dilemma many policy-makers are now facing is how to deal with subsequent waves of infection without inflicting damage to economic activity on the scale that was so apparent from measures deployed in response to the first wave. The present study attempts to inform these decisions by examining country experiences during the period to mid-August at a daily frequency, with a focus on how the reproduction number, $R$, (representing the spread of the virus), and mobility (as a proxy for economic activity), respond to policy measures. The study makes use of a set of Covid-19 policy trackers maintained by the Oxford Blavatnik School of Government (Hale et al., 2020) as well as some complementary indicators developed specifically for this project.

2. Since the onset of the pandemic, parameterised epidemiological models (the so-called SIR models; Susceptible, Infected and Recovered) have been a popular tool to analyse disease dynamics (Anderson et al., 2020; Atkeson, 2020; Stock, 2020). These models can be used to shed light on the impact of physical distancing and other public health measures in containing a second wave of infections (Ferguson et al., 2020; Matrajt and Leung, 2020; Davies et al., 2020; Hornstein, 2020). SIR models rely on several parameters (for instance to quantify the impact of physical distancing on $\mathrm{R}$ ), so their insights are only as good as these parameters are accurate. So far, however, most modellers have relied on past (mostly flu) epidemics to calibrate important parameters, while the current pandemic likely differs in important ways.

\footnotetext{
${ }^{1}$ Égert, Guillemette and Turner are members of the OECD's Economics Department. Murtin is member of the OECD'S Centre for Well-Being, Inclusion, Sustainability and Equal Opportunity. Email addresses: Balazs.EGERT@oecd.org; Yvan.GUILLEMETTE@oecd.org; Fabrice.MURTIN@oecd.org; David.TURNER@oecd.org. The authors would like to thank Laurence Boone, Luiz de Mello, Alain de Serres, colleagues from the Economics Department and participants at the October 2020 Working Party No. 1 meeting of the OECD Economic Policy Committee, for useful comments and suggestions. Special thanks go to Théodore Humann for excellent research assistance. Many thanks also go to Veronica Humi for excellent editorial assistance.
} 
3. This study contributes to a burgeoning literature that seeks to quantify the impact of government interventions on disease progression and on mobility employing reduced-form econometric estimates for the Covid-19 pandemic itself. This literature has already shown that stricter lockdown policies go in tandem with a reduction in Covid-19-related deaths (Conyon et al., 2020). It has found strong evidence that banning mass gatherings is one of the most effective ways of taming the spread of the virus (Ahammer et al., 2020; Hunter et al., 2020; Weber, 2020). Similarly, air travel restrictions are found to be effective, especially those imposed on international flights and at the early stages of the pandemic (Hubert, 2020; Keita, 2020, Leffler et al., 2020). Stay-at-home requirements and workplace closures can also curb the propagation of the disease (Deb et al., 2020a; Hunter et al., 2020; Weber, 2020), as can the use of face masks (Hatzius et al., 2020; Leffler et al., 2020; Mitze et al., 2020). Nevertheless, the recent empirical literature has said little about the importance of testing and contact tracing policies, despite their prominence in SIR models, and the protection of the elderly population.

4. The findings of this paper are consistent with much of the above literature. Containment policies can successfully reduce the spread of the virus, but most -- in particular stay-at-home requirements, workplace closures and school closures -- have a substantial impact on reducing mobility and by implication economic activity. Most importantly, unlike earlier empirical studies, the results strongly support the view that testing, combined with effective contact tracing are key components of the post-lockdown strategy, especially at relatively low level of infections (OECD, 2020a). This corroborates a recent outbreak modelling study (Hellewell et al., 2020), which found that contact tracing and isolation would only contain outbreaks of Covid-19 if very high levels of contact tracing were achieved. This is also consistent with the view that testing and tracing is most effective in a low-infection environment, because contact tracing becomes increasingly difficult with higher levels of new daily infections (OECD, 2020a). Furthermore, estimation results suggest that mask-wearing and the protection of the elderly population in general, and those in care homes in particular, might play an important role in combatting the virus.

5. Scenario analysis, based on empirical results in the paper, suggests that avoiding further lockdowns will require a wide-ranging package of public health polices, including a comprehensive regime of test, trace and isolation, mask-wearing mandates, isolation of those who are most vulnerable, and policies targeted at care homes. Moreover, unlike containment measures, these public health policies should have little adverse impact on mobility or economic activity. These findings are in line with and complement Acemoglu et al. (2020), who show in a multi-group SIR framework that the trade-off between mortality rates from the virus and economic damages can be attenuated if interventions are targeted on the most vulnerable individuals.

6. Public health policies may, however, need to be complemented by extending some containment measures, such as restrictions on large public gatherings or international travel, for which the aforementioned trade-off is most favourable. This is also because the most stringent and effective form of public health measures may have other costs, or be otherwise difficult to implement fully: many countries have struggled to roll-out comprehensive testing regimes; contact tracing becomes more difficult at higher levels of infections; banning visits to care homes is likely to cause distress for residents near end-of-life or suffering from dementia; and discriminating against certain groups, such as the elderly, who may be more vulnerable may also be difficult.

7. The remainder of the paper is organised around two equations estimated for a large sample of countries on daily data up to mid-August: the first explains the evolution of the reproduction rate, $\mathrm{R}$, and the second explains mobility, as a proxy for economic activity. In the next section, various data issues underlying the empirical work are discussed (with further details on construction of $R$ provided in Annex A). The policy implications of the estimated equations are then illustrated with a number of stylised policy scenarios, starting from the first outbreak of the virus, through full lockdown and, most importantly, exploring alternative strategies that would help keep the virus at bay. 


\section{Box 1. Policy option to reduce exposure to the COVID-19 virus}

Recent optimistic news about the availability of a number of vaccines against the coronavirus needs to be tempered by the realisation that, even in the countries that are in the vanguard, it is likely to be the middle of next year before a large share of the population has been vaccinated. In the meantime, governments around the world will be trying to calibrate policy interventions so as to keep the spread of the disease under control without crippling economic activity.

This study uses country experience during the first phase of the pandemic to estimate the impact of different government interventions on both the reproduction rate of the virus, $\mathrm{R}$, and on mobility, as a proxy for economic activity. The empirical results then inform a number of scenarios where the epidemic/economic trade-off of different policy packages is assessed:

- When the daily infection rate is high, a comprehensive combination of containment policies is needed to reduce the spread of the virus, although these are likely to severely reduce mobility and economic activity.

- Once the daily infection rate has been lowered, test-and-trace policies represent a better alternative for controlling the virus, because they have no significant adverse impact on mobility or economic activity. Testing is found to be more effective in reducing $R$ if accompanied by comprehensive contact tracing. Specific testing in care homes is also important to control the spread of the virus.

- Other public health policies can also contribute to restraining the spread of the virus, including: mandating mask-wearing in public indoor environments; restricting visits to care homes; and stay-at-home recommendations for the elderly population.

- Even with a comprehensive test-and-trace regime and supporting public health policies, there may be a need to resort to selective containment measures. These should prioritise restrictions on large gatherings and international travel. Where there are localised outbreaks of the virus, then targeted lockdown measures are appropriate.

\section{Stylised facts about the reproduction rate, mobility and containment, testing and other public health policies}

\subsection{The reproduction rate}

8. Estimates of the reproduction number, R, are constructed separately for each country using an approach adapted from the epidemiological literature and daily series on confirmed infections and deaths from the European Centre for Disease Prevention and Control (ECDC) (see Annex A for a detailed explanation). The median $\mathrm{R}$ estimate for a worldwide sample of approximately 70 countries fell from around 3 in February to around 1 in early May and has remained stable since (Figure 1, Panel A). This, however, hides considerable cross-country variation, with $\mathrm{R}$ nearing 1.5 in October in European countries, before a further set of major lockdown measures was implemented (Figure 1, Panel B). 
Figure 1. Median and interquartile range for effective reproduction rate (R)

A. Worldwide sample

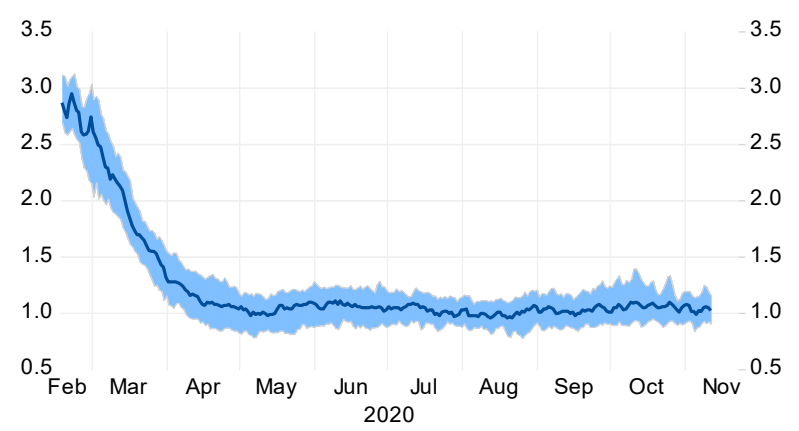

B. European sample

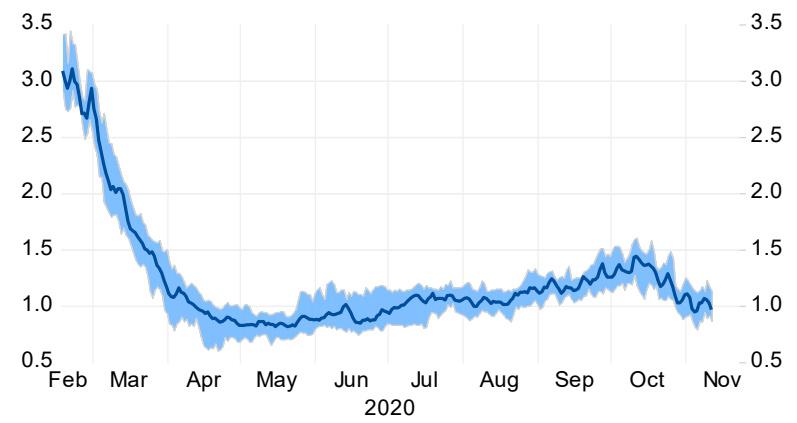

Note: The chart summarises trends in R for a selection of worldwide (Panel A) or European (Panel B) countries for which R can be computed over the full sample period.

Source: Authors' calculations derived from data on deaths and infections, see Annex A for details.

\subsection{Containment policies and mobility}

9. Many of the containment measures introduced by governments have had the objective of physical distancing. In the absence of a precise measure of physical distancing, high-frequency data on mobility provide a reasonable proxy. Such data are made available by Google, based on the movement of people with Android-based smartphones and with 'location history' turned on in their settings. The data are available for more than 130 countries at a daily frequency. The series measure the change in mobility from a same-day-of-the-week average in January and early February. ${ }^{2}$ In many countries that imposed lockdowns, mobility fell by as much as $70 \%$ in late March and April, relative to the pre-lockdown period. There is a manifest link between mobility and GDP at a quarterly frequency (Figure 2) and mobility is used as a focus in the current analysis because good quality indicators of economic activity at a higher frequency with broad country coverage are not readily available.

\footnotetext{
2 The mobility data are available for six location categories (grocery and pharmacies, parks, residential, retail and recreation, transit station and workplaces). This study works with a mobility index that is a linear combination of those six categories, giving greater weights to workplaces and transit stations. However, the six measures are highly correlated and a different weighting would have little influence on the results and conclusions.
} 
Figure 2. Link between mobility and GDP forecast revisions at a quarterly frequency for 2020 Q1 and Q2

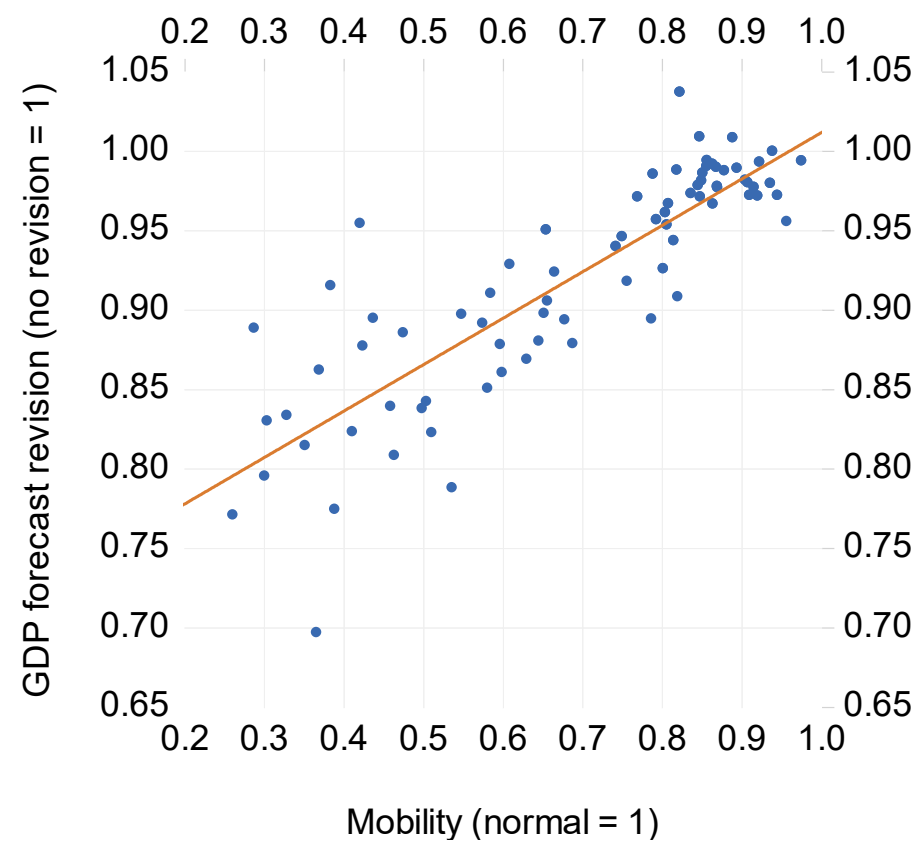

Note: The vertical axis is the ratio of the latest GDP estimate (or official outturn) to the projected level for the corresponding quarter in the December 2019 OECD Economic Outlook. Each dot represents a country/quarter combination. The chart covers OECD and BRIICS countries. Source: Google LLC, Google COVID-19 Community Mobility Reports, https://www.google.com/covid19/mobility; OECD Economic Outlook No. 106 and 107 databases; and OECD calculations.

10. The empirical analysis here relies on a set of variables representing containment measures maintained by the Oxford Blavatnik School of Government (Hale et al., 2020), which in their original form are scored according to the degree of stringency or comprehensiveness with which they are applied. Eight categories of containment measures are distinguished (Figure 3 , Table 1), being variously scored 0 to 2 , 0 to 3 , or 0 to $4 .{ }^{3}$ For the purposes of estimation, the cardinal value of these scores are ignored (as there is no reason, for example, to expect a policy with a stringency value of 3 to have treble the effect of a policy with a value of 1) and instead the same policy at different levels of stringency are included as distinct dummy variables (taking the value of zero or one). Subsequently, if the estimation does not deliver the expected ordinal ranking in coefficients (so that a more stringent application of a policy has a greater effect), the same coefficient may be imposed across different levels of stringency by combining policy variables. ${ }^{4}$

\footnotetext{
${ }^{3}$ The scoring of measures refers to their design, not necessarily how they have been applied. This represents a potential weakness as the variables do not capture how enforcement and abidance by regulations has varied across countries.

${ }^{4}$ Multicollinearity, implying problems in being able to separately identify coefficients on different explanatory variables, might be an obvious concern given that containment measures were often introduced simultaneously or very close together. However, the estimation here mitigates this problem by having a large country sample, daily frequency of observations and by distinguishing the stringency of such measures. Consequently, the correlations between containment measures variables used in the regressions are mostly far from unity. A possible exception is that there appears to be a degree of multicollinearity between variables representing school closure, workplace closure and stayat-home requirements, which means some caution is required in interpreting specific coefficients as discussed in the text.
} 
Figure 3. Percentage of countries at different stringency levels for containment policies according to the Oxford Covid-19 Government Response Tracker

A. School closing [0-3]

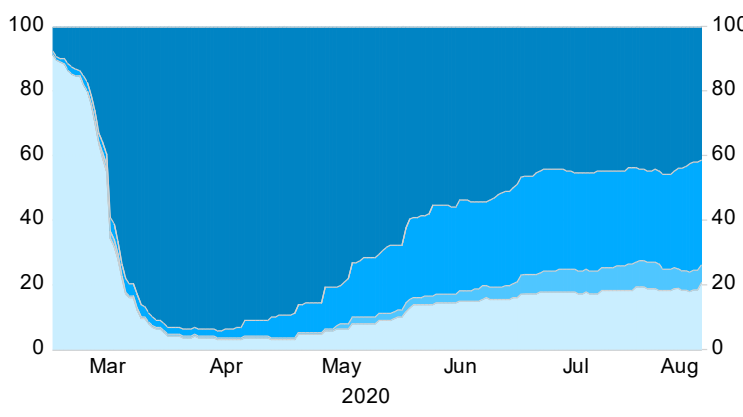

C. Cancel public events [0-2]

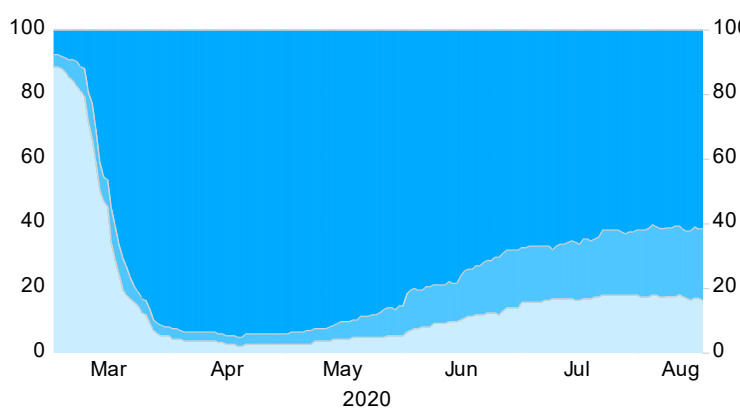

E. Close public transport [0-2]

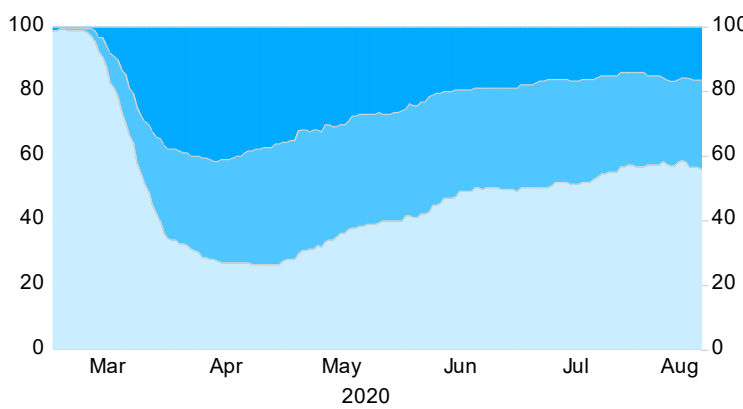

G. Restrictions on internal movement [0-2]

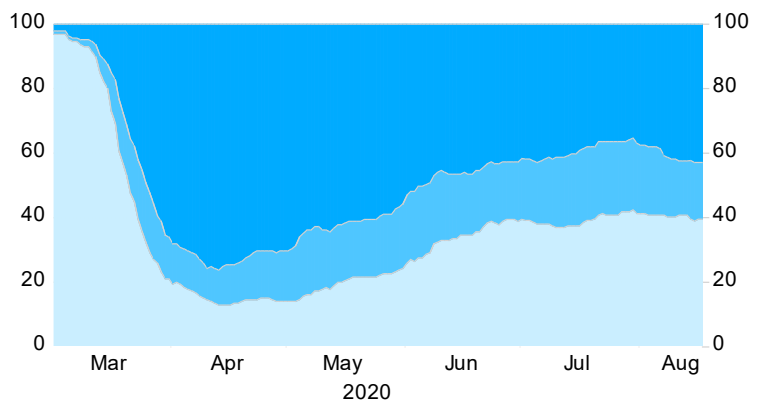

B. Workplace closing [0-3]

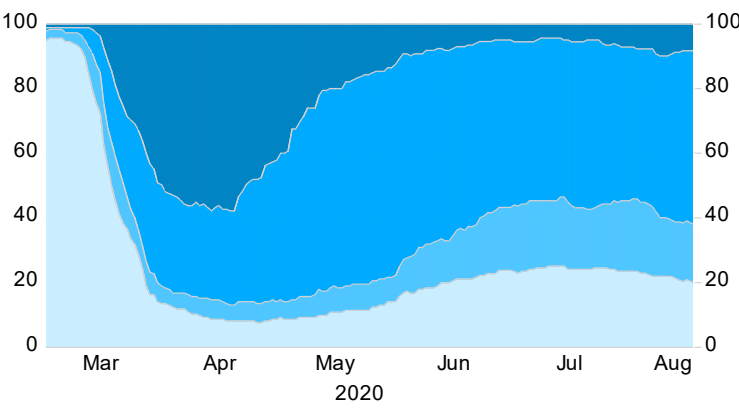

D. Restrictions on gatherings [0-4]

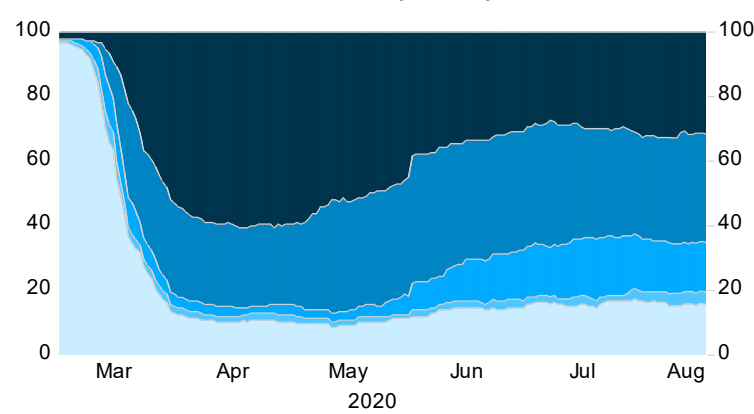

F. Stay at home requirements [0-3]

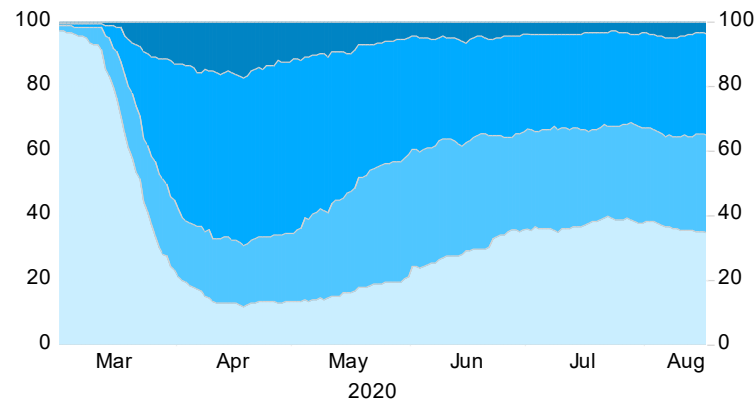

H. International travel controls [0-4]

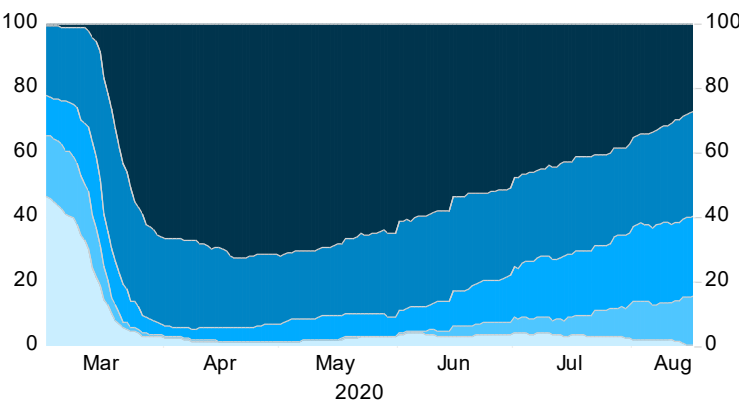

Note: Stringency is evaluated as an ordinal index, with a higher number representing higher stringency. Each panel subtitle indicates the range for that category. The charts are based on the source's full country coverage for a given date, at most 185 countries.

Source: Authors' calculations based on Hale et al. (2020). 
Table 1. Scoring of different stringency levels of containment policies according to the Oxford Covid-19 Government Response Tracker

\begin{tabular}{|c|c|}
\hline Containment measure & Scoring of degree of stringency \\
\hline \multirow[t]{3}{*}{ School closures } & 1: Recommend closing \\
\hline & 2: Require closing (only some levels or categories, eg just high school, or just public schools) \\
\hline & 3: Require closing all levels \\
\hline \multirow[t]{3}{*}{ Workplace closures } & 1: Recommend closing (or work from home) \\
\hline & 2: Require closing (or work from home) for some sectors or categories of workers \\
\hline & 3: Require closing (or work from home) all-but-essential workplaces (e.g. grocery stores, doctors) \\
\hline \multirow[t]{2}{*}{ Cancel public events } & 1: Recommend cancelling \\
\hline & 2: Require cancelling \\
\hline \multirow[t]{4}{*}{ Restrictions on gatherings } & 1: Restrictions on very large gatherings (above 1000 people) \\
\hline & 2: Restrictions on gatherings between 101-1000 people \\
\hline & 3: Restrictions on gatherings between $11-100$ people \\
\hline & 4: Restrictions on gatherings of 10 people or less \\
\hline \multirow[t]{2}{*}{ Close public transport } & 1: Recommend closing (or significantly reduce volume/route/means of transport available) \\
\hline & 2: Require closing (or prohibit most citizens from using it) \\
\hline \multirow[t]{3}{*}{ Stay at home requirements } & 1: Recommend not leaving house \\
\hline & 2: Require not leaving house with exceptions for daily exercise, grocery shopping, and 'essential' trips \\
\hline & 3: Require not leaving house with minimal exceptions (e.g. only once a week, or one person at a time) \\
\hline \multirow[t]{2}{*}{ Restrictions on internal movement } & 1: Recommend not to travel between regions/cities \\
\hline & 2: Internal movement restrictions in place \\
\hline \multirow[t]{4}{*}{ International travel controls } & 1: Screening \\
\hline & 2: Quarantine arrivals from high-risk regions \\
\hline & 3: Ban on arrivals from some regions \\
\hline & 4: Ban on all regions or total border closure \\
\hline
\end{tabular}

Note: Not shown in the table, but "No measures" or "No restrictions" are always scored 0.

Source: Hale et al. (2020).

\subsection{Test, trace and isolation policies}

11. Evidence for a large cross-section of countries suggests a negative correlation between the number of tests and mortality rates (Liang et al., 2020). Testing can break the chain of transmission and prevent the local outbreak of new infections, but to be effective requires the scale of testing to be ramped up quickly, a high accuracy of testing and the ability to carry out testing swiftly, which many countries struggled with during the first wave of Covid-19 (OECD, 2020a).

12. It has been argued that repeated mass testing coupled with the isolation of the infected would eradicate the virus without reliance on contact tracing (Taipale, Romer and Linnarsson, 2020). China has demonstrated the potential for mass testing in the city of Wuhan in May, with up to 1.5 million tests being processed in a single day (New York Times, 2020a). In early November 2020, Slovakia tested two-thirds of the country's population using rapid antigen tests (Euronews, 2020). Antigen tests provide results more quickly (within 30 minutes) compared to conventional PCR tests. While they are less accurate and miss some of the asymptomatic cases, experts argue these cases are likely to be less infectious (New York Times, 2020b).

13. Unless testing can be carried out quickly and on a truly mass scale, testing also needs to be accompanied by tracing the persons who have been in contact with the infected person. The effectiveness of testing and tracing crucially depends on the coverage of the contact persons. Its success also hinges on the speed with which the tests are carried out and the contact persons identified, tested and isolated if 
tested positive (Hellewell et al. 2020). Scenario analysis shows that a high level of testing in tandem with widespread and timely contact tracing and isolation may prevent a subsequent surge in infection rates (Panovska-Griffiths et al. 2020). Scaling-up contact tracing is difficult, but not impossible. ECDC (2020c) recommends: the use of well-trained non-public-health staff and volunteers; repurposing existing resources such as call centres; and using new technologies such as contact management software and mobile apps. Widespread testing and contact tracing is considered by many as a crucial part of policy packages during the de-confinement phase (Aleta et al., 2020; ECDC, 2020c).

14. To capture the effect of track-and-contact-trace policies, the policy indicators from the Blavatnik School of Government at the University of Oxford (Hale et al., 2020) are used, which in their original form are also scored according to the comprehensiveness of the testing or tracing regime (Table 2). They suggest there was a substantial improvement in the number of countries increasing the extent of their test and trace policies in the 2-3 months from March, but further increases since then have been modest (Figure 4). However, for the estimation work reported here, the cardinal values of these scores are again ignored and instead different dummy variables are used to represent test-and-trace variables at different degrees of comprehensiveness. An additional variable, constructed by the authors and described below, considers the importance of specific testing in care homes (Table 3). However, an important limitation of these indicators is that none cover issues of timing which can be key to a successful strategy: tests need to be done quickly and with a minimum delay before the results are available and then contacts need to be traced quickly. On the other hand, many issues relating to testing, including timing, may be easier when the level of infections is lower, and this can be readily tested in the empirical framework.

\section{Table 2. Scoring of the Oxford testing and contract tracing policy variables}

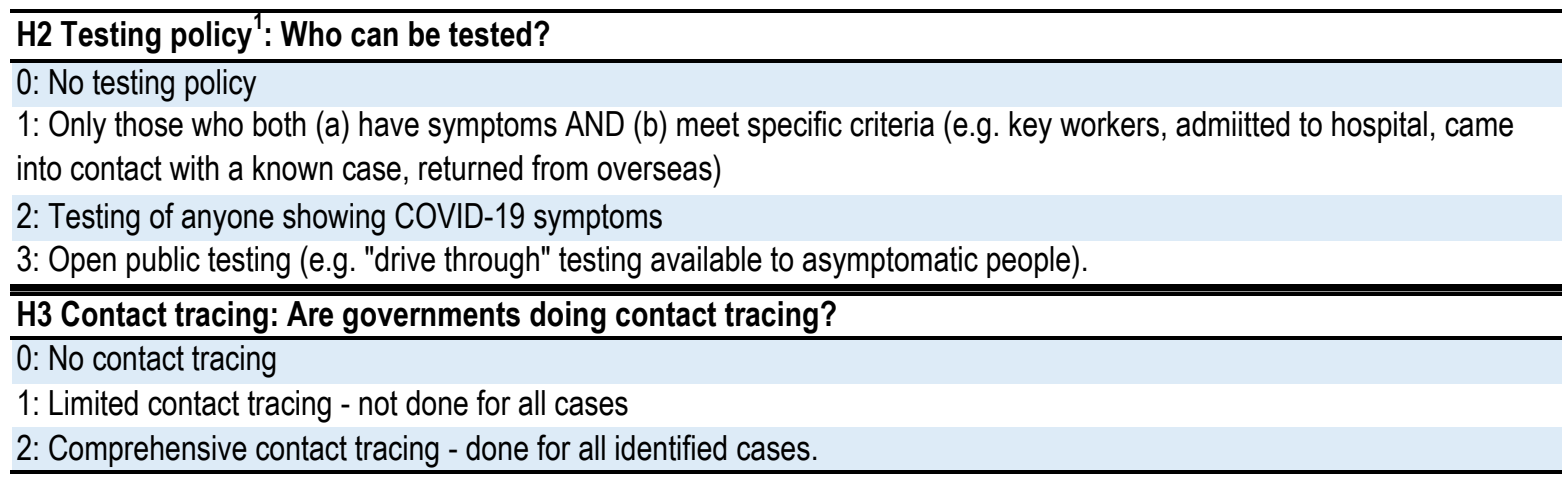

Note: (1) Testing variable relates to policies testing for infection (PCR test), not to policies testing for immunity (antibody tests). Source: Hale et al. (2020). 


\section{Figure 4. Percentage of countries at different stringency levels for testing and contact tracing policies according to the Oxford Covid-19 Government Response Tracker}
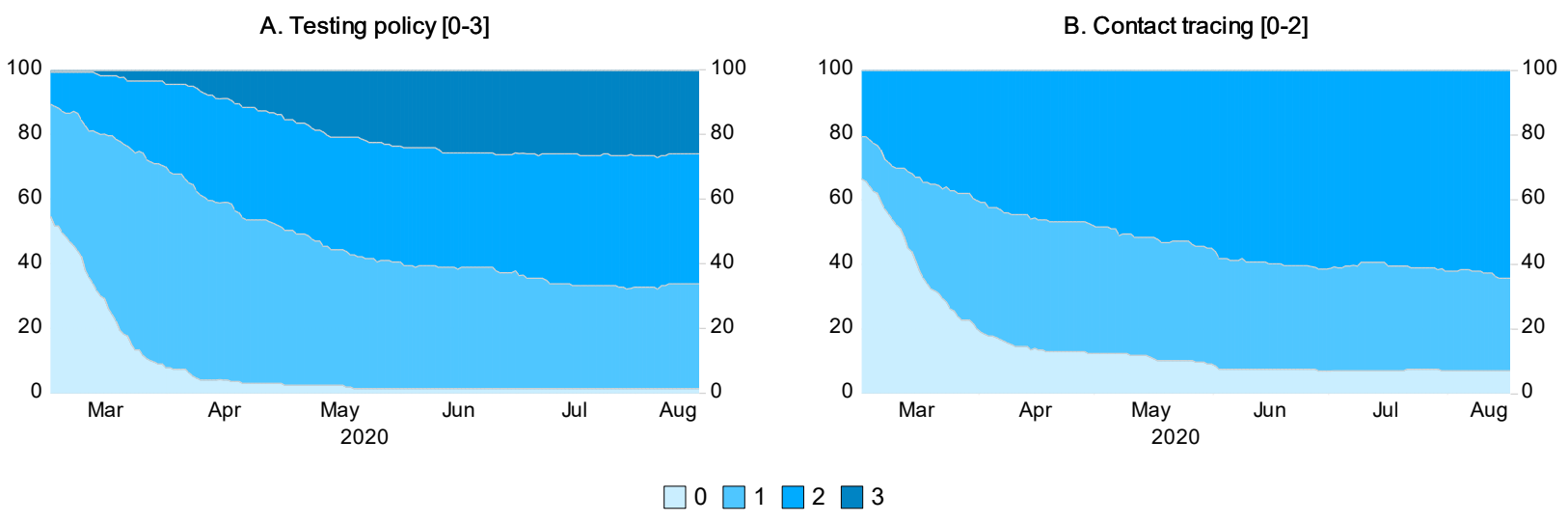

Source: Authors' calculations based on Hale et al. (2020).

\subsection{Shielding the elderly}

15. The elderly population is especially vulnerable to Covid-19 with much higher mortality rates than other demographic groups. A particular concern is that mortality rates have been very high in care/elderly/retirement homes (henceforth referred to as 'care homes') in some OECD countries (ECDC, 2020b; Gandal et al. 2020). Evidence, concerning experience in care homes with managing influenza outbreaks as well as the current pandemic, suggests that improving hygiene, including regular hand sanitising and disinfection at the establishment level (Koshkouei et al., 2020), as well as limiting the migration of staff across different care homes help to reduce infection rates substantially (Koshkouei et al., 2020; Chen et al., 2020), although the latter may be difficult given widespread staff shortages.

16. Empirical evidence is less clear-cut for testing staff and residents, and limiting visitors, even though these measures could be part of any infection management. Testing in care homes is particularly appealing, especially if testing capacities are limited. Testing should target potential super-spreaders (e.g. healthcare professionals) or groups of people who may find it difficult or impossible to comply with physical distancing, such as the elderly in packed care homes where several people live in the same room (OECD, 2020a). Some argue that these high-risk groups should be regularly tested even in the absence of symptoms (Grassly et al., 2020).

17. The current empirical work tests for the effectiveness of three types of government policies using variables constructed by the authors: firstly, recommendations to persuade the elderly to stay at home; secondly, restricting visits to care homes; and thirdly, testing of residents and/or staff of care homes (Table 3). Measures to specifically protect the elderly were relatively rare in mid-March, but have become more common across countries since then (see Table 4 for OECD countries). ${ }^{5}$

\footnotetext{
${ }^{5}$ These variables as well as the mask wearing variable are constructed using text search in three Covid-19-related databases: the COVID-19 Government Measures Dataset, run by the Assessment Capacities Project (ACAPS); $\underline{a}$ database on government responses to the coronavirus compiled by the CoronaNet Research Project; and the CCCSL dataset of the Complexity Science Hub Vienna. These record press and government statements with regard to public policy interventions to reduce the spread of Covid19, obtained from media, government communications and press releases from the United Nations and other international organisations. For every variable, a search is carried out for one or several keywords and the results are evaluated and coded. A potential shortcoming of this approach is that government policies not discussed publicly, or not communicated actively, might not appear in these datasets and hence might not be included in the analysis.
} 


\subsection{Mask-wearing}

18. Evidence increasingly suggests that face masks can provide a potentially powerful protection against the transmission of SARS-CoV-2, which travels through droplets dispersed in the air ( $\mathrm{He}$ et al., 2020, Lau et al 2020). This is especially true in closed and densely packed spaces and because a considerable share of infected people show no symptoms but have a high viral load. Meta-analysis of a large number of non-clinical trials of various coronaviruses indicates that mask wearing reduces significantly the infection rate, especially for masks of the N95 type (Chu et al. 2020; Schünemann et al., 2020), but even cloth masks are found to block infection (Mills et al. 2020). More direct evidence for SARSCoV-2 comes from small-scale clinical trials, which confirm the desirability of mask wearing in public (Raina et al., 2020). ${ }^{6}$

19. Measuring the health-effects of mask-wearing at the regional or country-level, based on public policy pronouncements, is difficult because they might depend on the take-up rate and correct use (covering both mouth and nose) and it is difficult to account for the greater tendency to wear face masks, regardless of policy pronouncements, in some (mostly Asian) countries prior to the current virus outbreak. Nevertheless, recent studies provide empirical support for the beneficial effects of mask wearing. For instance, in a large cross-sectional dataset, public mask wearing was found to be negatively related to mortality (Leffler et al., 2020). Another country-level study sheds light on the negative correlation between mask wearing and infections for U.S. counties and two different cross-sectional datasets (Hatzius et al., 2020). Finally, Mitze et al. (2020) conclude that mask wearing successfully lowered infection rates in German regions adopting compulsory mask wearing policies. Countries have been mandating mask wearing more forcefully. While few countries had mandatory mask wearing in closed public spaces in midMarch, a majority of OECD countries had adopted such measures by end-July (Table 4).

20. In the current empirical framework, mask wearing is investigated using variables constructed by the authors, which denote whether there is an obligation to wear masks in shops, public transport or more generally in closed spaces (Table 3).

\section{Table 3. Scoring of additional public health measures}

\begin{tabular}{ll}
\hline Public health measure & Scoring of degree of stringency \\
\hline $\begin{array}{ll}\text { Protection of the elderly } \\
\text { Testing in care homes }\end{array}$ & $\begin{array}{l}\text { 1: Testing of residents and/or staff in care homes, regional level } \\
\text { 2: Testing of residents and/or staff in care homes, national level }\end{array}$ \\
$\begin{array}{ll}\text { Restricting visits to care homes } & \text { 1: Ban on visits, regional level } \\
& \text { 2: Ban on visits, national level }\end{array}$ \\
\begin{tabular}{ll} 
Keeping the elderly at home & 1: Government recommendation to stay at home \\
Mask wearing & \\
Compulsory mask wearing indoors & 1: Mandatory at the local level \\
& 2: Mandatory nationwide \\
\hline
\end{tabular}
\end{tabular}

Source: Constructed by the authors using text search in three Covid-19-related databases.

Source: Authors.

\footnotetext{
6 There is also mounting anecdotal evidence in favour of mask wearing: a sick traveller wearing a mask not infecting fellow passengers; sick hairdressers not contaminating mask-wearing clients; and Starbucks employees in Korea wearing a mask not catching Covid-19 while customers were infected by a super-spreader individual (Bai, 2020).
} 


\subsection{Induced cautious behaviour and towards achieving herd immunity}

21. In addition to the variables representing policy responses, the regression analysis also includes different measures of the death rate from the virus as explanatory variables. ${ }^{7}$ Both the national and global daily death rates are included to proxy for general awareness of the virus prompting more cautious behaviour, for example voluntary physical distancing and increased hand-washing. The importance of these variables is that they proxy for changes in behaviour that are likely to be engendered regardless of government-mandated restrictions. In the case of the United States, for instance, Goolsbee and Syverson (2020) found that visits to businesses declined by up to $60 \%$ because of the pandemic, but that legal restrictions explained only 7 percentage points of this drop. Individual choices were far more important and seemed tied to fears of infection as differences in consumer traffic across counties were highly influenced by reported Covid-19 deaths.

22. Total national deaths attributed to the virus expressed as a share of the population are also separately included, as a proxy for the share of the population that has been infected, with the expectation of a negative coefficient; as the share of the population that has been infected rises (and presumably becomes immune), the speed with which the virus spreads will be reduced.

\footnotetext{
${ }^{7}$ A possible concern with using death rates as proxies on the right-hand side of the equation is that the left-hand side variable (reproduction rate) is already partly estimated based on deaths. This potential problem is attenuated by differences in timing, however. While timing can only be addressed imperfectly because the raw data on deaths are smoothed, the idea is that the reproduction rate for day $t$ is based on infections confirmed on day $t+12$ and on deaths recorded on day $t+22$. These leads are incorporated to account for average delays between infections and case detection, as well as average delays between infection and deaths, in the epidemiological literature (see Annex A). In any case, the coefficients on the policy variables of interest are reasonably robust to excluding the death variables from the $\mathrm{R}$ regression, although they increase to some extent.
} 
Table 4. OECD countries scoring highly on specific policies

\begin{tabular}{|c|c|c|c|c|}
\hline $\begin{array}{l}\text { Month first } \\
\text { implemented }\end{array}$ & $\begin{array}{l}\text { Recommend elderly stay- } \\
\text { at-home }\end{array}$ & $\begin{array}{l}\text { Restrict visits to } \\
\text { care homes }\end{array}$ & Test in care homes & $\begin{array}{l}\text { Mandate mask wearing } \\
\text { indoors }\end{array}$ \\
\hline \multirow[t]{15}{*}{ March } & Czech Repubic & Austria & Norway & Switzerland \\
\hline & Finland & Canada & Czech Republic & \\
\hline & Hungary & Chile & Lithuania & \\
\hline & Ireland & Czech Republic & Sweden & \\
\hline & Mexico & Denmark & United States & \\
\hline & Netherlands & Finland & & \\
\hline & Slovakia & Germany & & \\
\hline & Slovenia & Hungary & & \\
\hline & Spain & Israel & & \\
\hline & United States & Italy & & \\
\hline & & Luxembourg & & \\
\hline & & Netherlands & & \\
\hline & & Portugal & & \\
\hline & & Slovakia & & \\
\hline & & United States & & \\
\hline \multirow[t]{8}{*}{ April } & Poland & Sweden & Austria & Canada \\
\hline & & Switzerland & Belgium & Chile \\
\hline & & & Denmark & \\
\hline & & & Ireland & \\
\hline & & & Israel & \\
\hline & & & Luxembourg & \\
\hline & & & Portugal & \\
\hline & & & Switzerland & \\
\hline \multirow[t]{11}{*}{ May } & South Africa & Norway & & Austria \\
\hline & & Turkey & & Czech Republic \\
\hline & & & & Estonia \\
\hline & & & & Finland \\
\hline & & & & France \\
\hline & & & & Greece \\
\hline & & & & Israel \\
\hline & & & & Lithuania \\
\hline & & & & Portugal \\
\hline & & & & Slovakia \\
\hline & & & & Turkey \\
\hline \multirow[t]{2}{*}{ June } & & & & Japan \\
\hline & & & & Netherlands \\
\hline
\end{tabular}

Note: 'Mask-wearing indoors' denotes mandatory mask wearing in all closed public spaces.

Source: Variables constructed by the authors using text search in three Covid-19-related databases, see footnote 5. 


\section{Empirical evidence on the impact of policies on the reproduction rate and mobility}

23. This section describes the estimated effects of containment measures, testing policies, and other public health measures on both the reproduction rate, $R$ (Table 5), and mobility (Table 6), which underlie the policy scenarios presented in the subsequent section.

\subsection{The reproduction rate}

24. The (exponential of the) constant in the equations shown in Table 5 can be used to infer an average initial reproduction rate, R0, which is relevant at the start of an epidemic and applies to a population previously free of infection and before any containment or other public health policies have been implemented. R0 is not purely a feature of the virus - it depends on the conditions in which the virus emerges, for instance in terms of population density, social norms, etc. R0 would thus be expected to vary across countries, which is captured in estimation through the inclusion of country fixed effects. ${ }^{8}$

25. An important feature of the estimated equation explaining $R$ is that the preferred functional form for the dependent variable is logarithmic; a formal test decisively rejects a linear form in favour of a logarithmic one. ${ }^{9}$ This implies that any policy intervention will have a larger effect when $\mathrm{R}$ is initially high than when it is low, and underlines the merit of early policy interventions.

\subsubsection{Confinement policies}

26. In estimation, the coefficients on five containment policies -- workplace closures, restrictions on gatherings, stay-at-home requirements, international travel controls and school closures -- are found to have a statistically significant effect in reducing $R$ (Table 5). The coefficient on school closures has the largest effect of any containment policies, but there is a degree of collinearity between school closures, stay-at-home requirements and workplace closures arising because such containment policies have often been imposed at the same time.

27. Further testing suggests that while the sum of the coefficients on these three containment variables is a robust indication of the effect of a combined package, the coefficient on any one of them is less reliable as it is sensitive to the exclusion of other variables (and for this reason the combined effect of these three

\footnotetext{
8 The estimated equation includes a full set of country fixed effects to account for fixed country characteristics that could affect virus transmission. There are many such factors, including population density, general social habits, climate, etc. One possibility would be to attempt to include these factors individually, but some factors (such as social habits) are difficult to quantify and failure to account for some important ones could result in omitted-variable bias. Some differences across countries which have been associated with variations in mortality from Covid-19 in the epidemiological literature, such as prevalence of certain conditions or diseases (obesity, diabetes, cardiovascular diseases, etc.), would not necessarily be expected to affect virus, transmission itself, which is the dependent variable here. At the same time, estimation of the reproduction number relies in part on death counts, and there could also be an indirect link between mortality and virus transmission, for instance if a lot of transmission happens in health settings where more serious cases end up. In any case, the country fixed effects would also absorb cross-country differences in determinants of mortality.

${ }^{9}$ Testing the appropriate functional form of the dependent variable is not as straightforward as testing for the functional form of explanatory variables because the competing models cannot be nested within a general model. The test is therefore conducted by first transforming the dependent variable by dividing by its geometric mean to make the two competing models (log and linear) comparable. A formal test of model equivalence can be performed with the BoxCox statistic by comparing the relative goodness-of-fit of the two models. The test decisively favours the logarithmic form for $\mathrm{R}$ over different country samples. Conversely, when a similar test is carried out for the mobility equation, the linear form is decisively preferred to the logarithmic form.
} 
policies is summarised in Figure 5 and referred to as a 'Typical lockdown', rather than showing each of them individually). Similarly, the absence of any role for the closure of public events in the equation is likely related to its overlap with restrictions on the size of gatherings, which is included. The combined effect of applying all containment polices suggests that from an initial $\mathrm{R} 0$ value of about 3 , a complete package of containment measures would nearly halve the reproduction number. ${ }^{10}$

28. An interesting finding is that the impact differs substantially across countries: workplace closures have a considerably larger negative effect on $\mathrm{R}$ in high-income countries as compared to other countries. ${ }^{11}$ One possible reason may be that workplace closures can be enforced more effectively in high-income countries while workers, more likely to be covered by social insurance, may be less tempted to circumvent them. This finding is mirrored in the mobility equation: workplace closures have a larger impact in advanced economies. Conversely, while stay-at-home requirements are found to reduce $\mathrm{R}$ to a greater extent in advanced economies than in less developed countries, this is not the case for mobility. The lower effectiveness of stay-at-home requirements in less advanced economies may be attributable to larger household sizes and smaller living spaces (Table B.3 in Annex B).

29. An important feature of these results is that the full $R$ reduction is often achieved well before the maximum level of stringency is reached: for example a stringency score of 2 on the workplace closure variable reduces $R$, but it is not possible to detect any additional effect on $R$ from a further increase in the degree of stringency. The combined effect of applying all containment polices suggests that from an initial R0 value of about 3 , a complete package of containment measures would nearly halve the reproduction number (Figure 5). ${ }^{12}$

\footnotetext{
10 The OECD Economics Department compiled an alternative dataset of containment policies covering five areas: stay-at-home requirements, workplace closures, school closures, cancellation of public events and travel restrictions (Bulman and Koirala, 2020). While these indicators overlap with the Oxford measures, their definitions and coding differ. All policies are scored from 0 to 5 , except cancelling of public events, which ranges from 0 to 3 . Equations for $\mathrm{R}$ based on the OECD indicators include 74 countries and yield results broadly consistent with those based on the Oxford indicators: containment measures as a whole reduce $R$ substantially, even though the impacts of specific containment policies differ from the Oxford-based results. The estimated effects of public health policies do not change as well as the finding that test and trace policies are very effective in a low-infection environment (Table B.1 in Annex B). The OECD trackers of containment policies were discontinued as of October 2020.

11 The sample is divided into two groups of countries: those whose GDP per capita was greater than USD 25500 in 2018 in Purchasing Power Parity terms, and countries with lower per capita income levels.

12 Note that given the log specification of $R$ the effectiveness of policies in terms of their absolute effect on $R$ is nonlinear and weakens at lower initial values of $\mathrm{R}$. In addition, as described in the scenario analysis below, the effect on $\mathrm{R}$ from a full package of lockdown measures is likely to be enhanced by greater caution from the general population.
} 
Figure 5. Effect of containment policies and public health policies on (logged) $R$

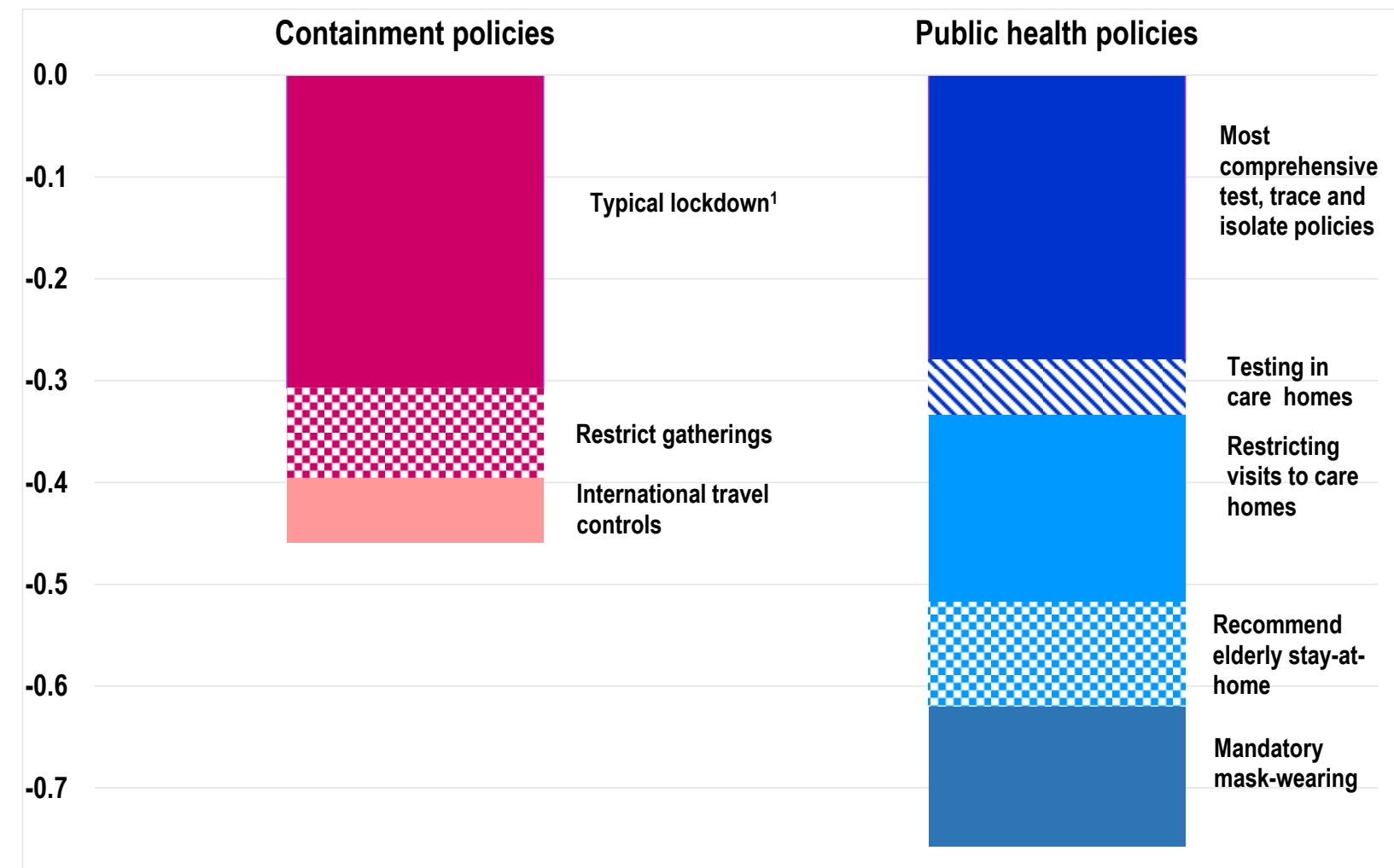

$-0.8$

Note: This chart decomposes the effect on (logged) R from the different containment policies (left hand side red bars) and public health policies (right hand side blue bars) according to the regressions in Table 5.

(1)The effects of school closures (>=2), stay-at-home requirements ( $>=1$ ) and workplace closures (>=2) have been combined into one segment labelled 'Typical lockdown'. This is both because such policies have often been imposed at the same time and, as discussed in the main text, because multi-collinearity means that the sum of the coefficients on these three containment variables are more reliable than any of the individual coefficients.

Source: Authors' calculations.

\subsubsection{Test and trace policies}

30. Results suggest that test and trace policies can reduce the spread of the virus (Table 5). The most comprehensive form of test and trace policies are more than $2 \frac{1}{2}$ times as effective in reducing $R$ than more limited forms. Test and trace polices are most effective when the infection rate is not too high (which in estimation is taken to be less than 10 new daily cases per million population, a rate which was well exceeded by many countries in March and April), a rather unsurprising finding given the difficulties of tracking down all contact persons in a timely manner if the system is overwhelmed with new cases. Overall, the effect of the most effective test and trace regime in an environment of low daily infection, is estimated to have a greater effect on reducing $R$ than any other public health interventions and is 2-3 times more effective than most individual containment measures (Figure 5). Variant regressions show that isolating the contacts of people who are sick or tested positive with the virus has a non-trivial effect on $R$ and enhances substantially the effectiveness of test and trace policies (Table B.5 in Annex B).

\subsubsection{Protecting the elderly}

31. The empirical analysis provides strong evidence that policies can play an important role in shielding the elderly population. Stepping up the testing of residents and staff in long-term care facilities is found to correlate negatively with the transmission of the virus. Restricting visitor access to these 
establishments goes in tandem with lower reproduction rates. Furthermore, general stay-at-home recommendations for the elderly appears to be associated with less infections (Table 5). The combined effect of these polices on reducing $R$ is estimated to exceed the effect of most individual containment measures, (Figure 5).

\subsubsection{Mask wearing}

32. Results show a sizeable and fairly robust negative effect on $R$ from the introduction of mandatory mask wearing in all closed public spaces (Table 5), although other results (not reported) suggest that extending mask wearing obligations to the outdoors does not appear to add much to reducing the reproduction rate.

\subsubsection{Awareness of the virus and towards herd immunity}

33. The death rate variables are statistically significant with the expected negative sign and their magnitudes imply they can play an important role in the evolution of $R$.

34. The daily death rates are postulated to induce more cautionary behaviour. The global daily death rate has fluctuated around 0.5 per million during the period considered which, from an initial value of R0 of 3 , would be expected to reduce $\mathrm{R}$ by about 0.6 . The national daily death rate varies substantially, both across countries and over time, but for some OECD countries it was running at around 15 per million going into the lockdown in March, and this would reduce $\mathrm{R}$ by a further 0.6 .

35. The total national death rate (i.e. based on cumulative deaths) also varies substantially across countries and has been increasing relentlessly through time in most countries. It is used here to proxy the profile of the number of people that have already been infected (and so are subsequently immune), so helping to reduce R. In a number of major OECD countries (including the United Kingdom, Spain, Italy and France) the total death rate currently exceeds 400 per million, at which level $\mathrm{R}$ would be reduced from 3 to $2.5 . .^{13}$

\footnotetext{
${ }^{13}$ The estimated coefficient on the total national death rate implies a herd-immunity threshold of about 1600 deaths per million population (or $0.16 \%$ ), since the estimated equation predicts that $\mathrm{R}$ would fall below one above this level of cumulative deaths. For an estimated average $\mathrm{RO}$ of 3.0, a standard epidemiological relationship predicts herd immunity once $(1-1 / 3)=67 \%$ of the population has been infected (assuming persistent immunity). Both findings are consistent with current estimates of the infection fatality rate (IFR) for Covid-19, which is heavily stratified by age but ranges from $0.1 \%$ to $0.4 \%$ at the population level (Oke and Heneghan, 2020). Indeed, this IFR range corresponds to a populationfatality rate of $0.07 \%$ to $0.27 \%(=67 \%$ * $[0.1 \%$ to $0.4 \%])$ for herd immunity. The estimated one $(0.16 \%)$ falls within this range.
} 
Table 5. The drivers of the reproduction rate

Sample period: 1 January to 17 August 2020

\begin{tabular}{|c|c|}
\hline \multicolumn{2}{|l|}{ Dependent variable: $\operatorname{In}(R)$} \\
\hline Constant & $1.0947^{* *}$ \\
\hline \multicolumn{2}{|l|}{ Containment policies } \\
\hline Stay-at-home requirement (>=1) & $-0.0536^{* *}$ \\
\hline Workplace closures (=1) & $-0.0614^{\star \star}$ \\
\hline Workplace closures (>=2) & $-0.0767^{* *}$ \\
\hline School closures (>=2) & $-0.1773^{* *}$ \\
\hline Restrictions on gatherings ( $=2$ ) & $-0.0393^{* *}$ \\
\hline Restrictions on gatherings (>=3) & $-0.0883^{* *}$ \\
\hline International travel controls $(>=1)$ & $-0.0629^{* *}$ \\
\hline \multicolumn{2}{|l|}{ Test and Trace policies } \\
\hline Test $=1$ or 2 , Trace $=1$ or 2 & $-0.1110^{* *}$ \\
\hline Test $=3$, Trace $=1$ & $-0.1364^{* *}$ \\
\hline Test $=3$, Trace $=2$ & $-0.2185^{\star *}$ \\
\hline All Test \& Trace combinations when deaths $<10$ per million & $-0.0613^{* *}$ \\
\hline \multicolumn{2}{|l|}{ Policies protecting the elderly } \\
\hline Testing in care homes $(=2)$ & $-0.0540^{* *}$ \\
\hline Restricting visits to care homes (>=1) & $-0.1840^{\star *}$ \\
\hline Recommending elderly to stay at home & $-0.1022^{* *}$ \\
\hline \multicolumn{2}{|l|}{ Other non-containment policies } \\
\hline Mandatory mask wearing indoors & $-0.1370^{* *}$ \\
\hline \multicolumn{2}{|l|}{ Death rates (per million population) } \\
\hline Daily national & $-0.0358^{* *}$ \\
\hline Daily global & $-0.3637^{* *}$ \\
\hline Total national & $-0.0007^{* *}$ \\
\hline Adjusted R-squared & 0.597 \\
\hline Daily observations & 17624 \\
\hline Countries covered & 147 \\
\hline Country fixed effects & Yes \\
\hline
\end{tabular}

Note: For details of the construction of data on R see Annex A. The policy variables are based on the variables described in Tables 1 to 3 in the main text, but re-normalised to be $(0,1)$ dummy variables as described in the main text. The notation in brackets "(=n)" after a containment policy variable denotes that the dummy variable is assigned a 1 if the original score for that policy was equal to $n$, whereas the notation "(>=n)" denotes that the dummy variable is assigned a 1 if the original score for that policy was greater than or equal to $n$. "**" denotes statistical significance at the $5 \%$ level, based on heteroscedasticity-robust standard errors.

Source: Authors' calculations. 


\subsubsection{The policy drivers of mobility}

36. Putting in place containment and isolation policies hinders the free daily movement of people. Empirical results ${ }^{14}$ suggest that seven of the eight categories of containment policies have a negative effect on mobility (Table 6). ${ }^{15}$ Unlike in the equation for $\mathrm{R}$, there is a clearer ranking in coefficients, so that the more stringent application of a particular policy tends to reduce mobility by more. For example: the most severe form of workplace closure (score of 3 ) has nine times the effect on mobility of the mildest form (score of 1). These findings suggest that moving to the more stringent forms of workplace closure, stay-athome requirements and school closure has large negative effects on mobility and hence economic activity, although it is difficult to detect any corresponding benefit from further reductions in R. ${ }^{16}$

37. For policies such as the cancellation of public events and travel restrictions, the most limited application of the policy has no significant effect on mobility. Applying all containment policies in their most severe forms would reduce mobility by more than half relative to normal, with $50 \%$ of this reduction accounted for by workplace closures and stay-at-home requirements.

38. Alternative estimations explore the effect of mask-wearing on mobility. The positive coefficient estimates suggest that mandating mask wearing in public transports and shops raises mobility. Similarly, more extensive testing and the isolation of contact persons are found to encourage mobility (Table B.6 in Annex B), possibly by reducing concerns about infection.

39. The national daily death rate from the virus is again included to proxy general awareness of the virus and its effect in voluntarily reducing mobility due to an increase in natural caution. A national daily death rate running at around 15 per million - similar to the rate experienced by some major OECD countries going into the lockdown in March - would reduce mobility by $10 \%$, independently of any government-mandated polices.

\footnotetext{
14 For the estimated equation explaining mobility, unlike that for $\mathrm{R}$, the preferred functional form for the dependent variable is linear, not logarithmic, which makes it more straightforward to evaluate the effect of policies. The specification includes a full set of country fixed effects to account for invariant country characteristics, although their inclusion is much less critical here given that mobility is a relative measure constructed so that it equals one in normal times in each country.

15 The failure to detect any effect from restrictions on gatherings is likely related to its close correlation with the policy to cancel public events.

${ }^{16}$ Using the OECD containment measures (covering 68 countries) yields very similar estimation results (Table B.2 in Annex B).
} 
Table 6. The drivers of mobility

Sample period: 1 January to 17 August 2020

\begin{tabular}{|c|c|}
\hline \multicolumn{2}{|l|}{ Dependent variable: Mobility } \\
\hline Constant & $1.0241^{\star *}$ \\
\hline \multicolumn{2}{|l|}{ Containment policies } \\
\hline Stay-at-home requirement $(=1)$ & $-0.0240^{*}$ \\
\hline Stay-at-home requirement (=2) & $-0.0668^{* *}$ \\
\hline Stay-at-home requirement $(=3)$ & $-0.1252^{* *}$ \\
\hline Workplace closures $(=1)$ & $-0.0216^{\star \prime}$ \\
\hline Workplace closures $(=2)$ & $-0.0491^{* \star}$ \\
\hline Workplace closures (=3) & $-0.1980^{* \star}$ \\
\hline School closures (=2) & $-0.0237^{* \star}$ \\
\hline School closures (=3) & $-0.1098^{* *}$ \\
\hline Cancel public events (=2) & $-0.0369^{* *}$ \\
\hline Restrictions on internal movement (=2) & $-0.0220^{* *}$ \\
\hline International travel controls $(=4)$ & $-0.0554^{* \star}$ \\
\hline Close public transport (=1) & $-0.0439^{*}$ \\
\hline Close public transport (=2) & $-0.0650^{*}$ \\
\hline \multicolumn{2}{|l|}{ Death rate (per million population) } \\
\hline Daily national & $-0.0066^{* *}$ \\
\hline Adjusted R-squared & 0.759 \\
\hline Daily observations & 22741 \\
\hline Countries covered & 128 \\
\hline Country fixed effects & Yes \\
\hline
\end{tabular}

Note: Mobility data are made available by Google, based on the movement of people with 'location history' turned on in their smartphone settings. The index used here measure the change in mobility from a same-day-of-the-week average in January and early February, so that normality would suggest an index of 1.0. The containment policy variables are based on those summarised in Table 1, but re-normalised to be $(0,1)$ dummy variables as described in the main text. The notation in brackets "(=n)" after a containment policy variable denotes that the dummy variable is assigned a 1 if the original score for that policy was equal to $n$, whereas the notation "( $>=n)$ " denotes that the dummy variable is assigned a 1 if the original score for that policy was greater than or equal to $n$. "**” denotes statistical significance at the $5 \%$ level.

Source: Authors' calculations.

\section{Scenario analysis}

40. As reported in the previous section, equations estimated for a large sample of countries find welldetermined effects from containment policies on $\mathrm{R}$ and mobility, as well as strongly significant effects from a range of health policies on $\mathrm{R}$. However, another important feature of both equations is that the prevalence of the virus is found to alter behaviour regardless of government-mandated policies: mobility is reduced and the general population is more ready to adopt physical distancing and other measures which reduce R. In order to draw out the policy implications of these estimations, a number of stylised scenarios are constructed using the estimated equations to follow the evolution of $R$ and mobility from the first outbreak of the virus, through full lockdown, followed by a number of alternative exit strategies (Figure 6, Table 7).

41. At the first outbreak of the virus, for the typical country, the initial reproduction number R0 is estimated to be about 3 and, before the impact of the virus is felt on the economy, mobility is normal 
(represented by the red triangle at the top right-hand-side corner of Figure 6). Even before the implementation of government-mandated measures, awareness of the seriousness of the virus (represented by the daily death rate) is likely to reduce mobility and foster more cautious behaviour, leading to a fall in R, although it remains well above 1.0 (the red triangle-labelled "Pre-lockdown + natural caution" in Figure 6 , which is calibrated on the daily death rates of a number of major OECD economies just prior to lockdown).

42. Once the number of daily infections is high (here proxied by the high national daily death rate), the implementation of a wide range of containment measures will be essential to contain the spread of the virus. In the scenarios considered here, the implementation of full lockdown (FLD) measures, accompanied by a limited test-and-trace regime, reduces $R$ to close to 1.0 , but at the cost of a sharp fall in mobility (represented by the blue squares in Figure 6). The degree of stringency with which lockdown measures are applied will determine the extent of the fall in mobility, with two scenarios considered here: the first assumes that containment policies are applied with a degree of stringency which is typical of that followed by countries in March/April (corresponding to the median country); the second assumes all containment policies to be applied to their maximum possible degree of stringency. Mobility falls by more than $40 \%$ in the former case and by more than $60 \%$ in the latter, however the estimation results suggest there is little additional benefit in terms of lowering $R$ from maximising the degree of stringency of containment policies (particularly with regard to workplace closures or stay-at-home requirements).

43. Even in the absence of further policy changes, the reproduction number will evolve during lockdown as the number of infections/deaths change the fall in the daily death rate may tend to lower natural caution and so lead to some increase in R and mobility; on the other hand, as the total number of individuals that have already been infected and are immune rises then this will tend to lower $R$. The estimation results and particular calibrations used in constructing these scenarios suggest these two effects roughly cancel each other out.

44. A number of strategies for avoiding a full lockdown are considered (represented by the green circles in Figure 6). The basic issue facing policy-makers is how to prevent the need for the full set of containment policies while bringing or keeping $R$ under control. The estimation results (Table 5) suggest that the implementation of a comprehensive test and trace policy together with a package of other public health measures would more than compensate for the removal of lockdown policies, so that their successful implementation would see a return to near normality of mobility, with $\mathrm{R}$ remaining below 1 (as represented by the green circle labelled "No LD + full health measures" in Figure 6).

45. An even more decisive reduction in $\mathrm{R}$ below 1 might be achieved, if comprehensive public health measures were accompanied by maintaining some containment policies (here assuming that restrictions on large public events, large public gatherings and international travel remain), although it would come at some cost to mobility (Partial LD + full health measures" in Figure 6).

46. In practice, as the experience of several countries is showing, implementing a full range of public health policies and a comprehensive test and trace regime may be difficult, especially once the daily infection rate has begun to rise. Variant scenarios with "limited health measures" assume only a limited test-and-trace regime together with mandating mask-wearing in indoor public places, but no other public health policies targeted at the elderly or care homes. Such a combination of policies accompanied by a full relaxation of lockdown measures might see mobility initially return to just below normal levels (assuming the daily death rate has previously been reduced by lockdown), but $\mathrm{R}$ will likely increase well above 1.0 (represented by the scenario labelled "No $L D$ + limited health measures" in Figure 6). However, this situation would not be a stable equilibrium, as with $R$ above 1.0 there would be a subsequent pick-up in infections and deaths, which in turn would further reduce mobility, regardless of further government action.

47. A limited set of health measures accompanied by maintaining the same limited containment policies, would come at a more immediate cost to mobility, but bring $\mathrm{R}$ down by more, although in the 
scenario considered here it would still remain above 1 ("Partial $L D+$ limited health measures"), and so would not represent a sustainable situation.

Figure 6. Stylised scenarios: from the first outbreak of the virus, through lockdown and exit

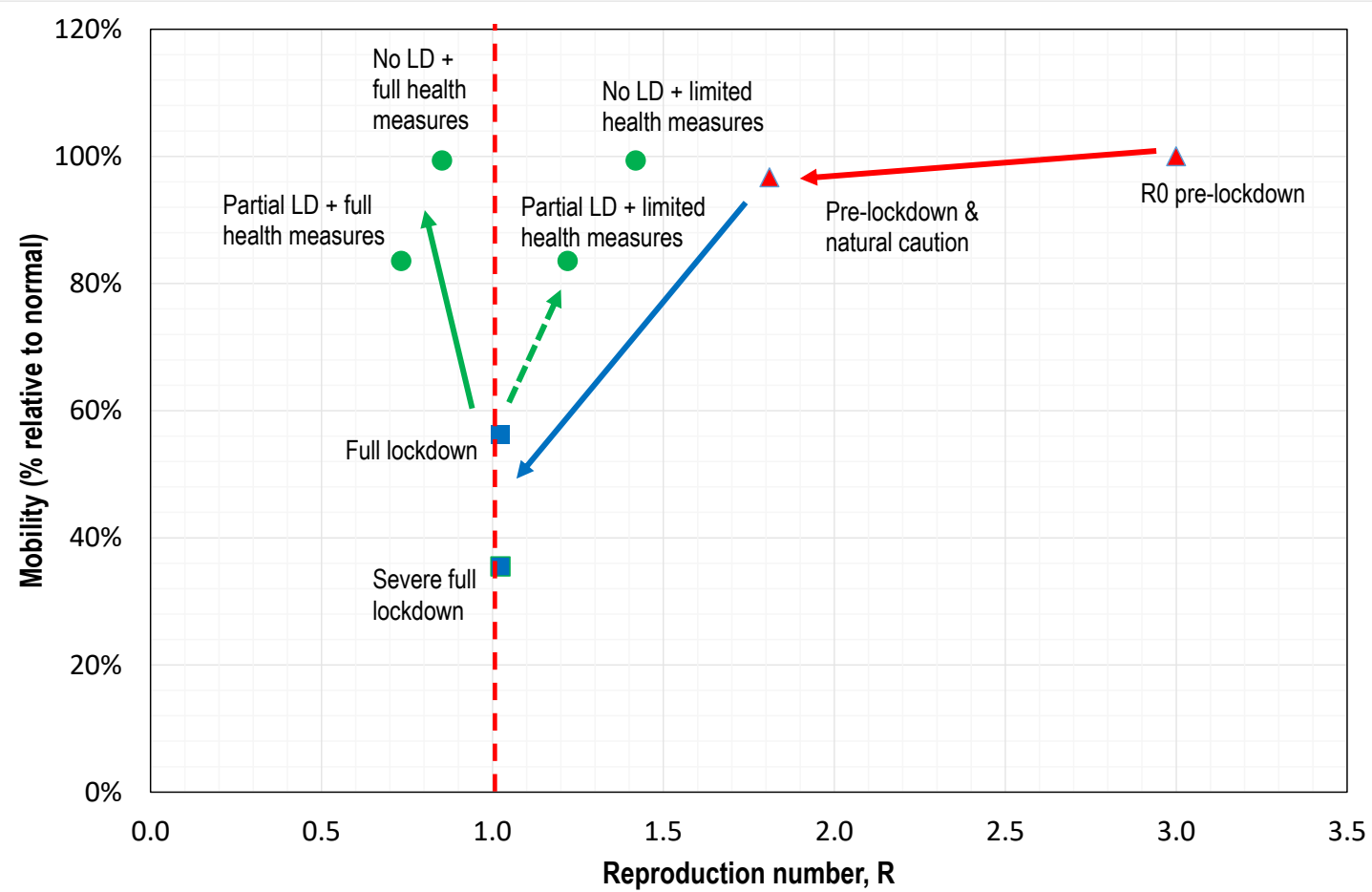

Note: The points represent scenarios, each of which are generated from consistent combinations of the equations for $\mathrm{R}$ and mobility using assumptions for the explanatory variables that are summarised in Table 7. The red triangles denote the situation at the start of the virus outbreak, blue squares the situation following full lock-down policies, and the green circles represent various exit scenarios.

Source: Authors.

Table 7. Scenario assumptions and outcomes for R and mobility

\begin{tabular}{|c|c|c|c|c|c|c|c|c|c|c|c|c|}
\hline \multirow{2}{*}{ Scenario } & \multirow{2}{*}{ Containment measures } & \multicolumn{2}{|c|}{$\begin{array}{l}\text { Testing,tracing \& } \\
\quad \text { isolation }\end{array}$} & \multicolumn{4}{|c|}{ Other public health policies } & \multirow{2}{*}{\multicolumn{3}{|c|}{ 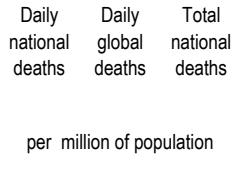 }} & \multirow{2}{*}{$\mathrm{R}$} & \multirow{2}{*}{$\begin{array}{c}\text { Mobility } \\
\text { index } \\
(1.00= \\
\text { normal })\end{array}$} \\
\hline & & Extensive & Limited & $\begin{array}{c}\text { Mask- } \\
\text { wearing }\end{array}$ & $\begin{array}{l}\text { Testing in } \\
\text { care } \\
\text { homes }\end{array}$ & $\begin{array}{l}\text { Elderly } \\
\text { stay at } \\
\text { home }\end{array}$ & $\begin{array}{c}\text { Ban care } \\
\text { home } \\
\text { visits }\end{array}$ & & & & & \\
\hline \multicolumn{13}{|l|}{ Pre-lockdown } \\
\hline RO & None & - & - & - & - & - & - & 0 & 0 & 0 & 3.00 & 1.00 \\
\hline Natural caution & None & - & - & - & - & - & - & 5.0 & 0.8 & 50 & 1.81 & 0.97 \\
\hline \multicolumn{13}{|l|}{ Lockdown } \\
\hline Full lockdown (FLD) & Comprehensive & - & $\sqrt{ }$ & - & - & - & - & 5.0 & 0.8 & 50 & 1.02 & 0.56 \\
\hline Severe FLD & Comprehensive \& severe & - & $\sqrt{ }$ & - & - & - & - & 5.0 & 0.8 & 50 & 1.02 & 0.35 \\
\hline \multicolumn{13}{|l|}{ Exit from lockdown } \\
\hline Partial LD \& full health measures & $\begin{array}{c}\text { Ban large public events, restrict gatherings, } \\
\text { quarantine international travellers }\end{array}$ & $\sqrt{ }$ & - & $\sqrt{ }$ & $\sqrt{ }$ & $\sqrt{ }$ & $\sqrt{ }$ & 1.0 & 0.7 & 300 & 0.73 & 0.84 \\
\hline Partial LD \& limited health measures & $\begin{array}{c}\text { Ban large public events, restrict gatherings, } \\
\text { quarantine international travellers }\end{array}$ & - & $\sqrt{ }$ & $\sqrt{ }$ & - & - & - & 1.0 & 0.7 & 300 & 1.22 & 0.84 \\
\hline No LD \& full health measures & None & $\sqrt{ }$ & - & $\sqrt{ }$ & $\sqrt{ }$ & $\sqrt{ }$ & $\sqrt{ }$ & 1.0 & 0.7 & 300 & 0.85 & 0.99 \\
\hline No LD \& limited health measures & None & - & $\sqrt{ }$ & $\sqrt{ }$ & - & - & - & 1.0 & 0.7 & 300 & 1.42 & 0.99 \\
\hline
\end{tabular}

Note: The assumptions here correspond to the scenarios illustrated in Figure 6.

Source: Authors' calculations. 


\subsection{Which lockdown policies should stay in place longest?}

48. The policy scenarios suggest that a prudent strategy would likely consist of imposing some lockdown policies, at least until it is clear that $\mathrm{R}$ remains decisively below 1 . This raises the question as to whether the estimations help to inform this choice by suggesting policies with a better trade-off in terms of the benefit from virus control relative to the cost in terms of mobility foregone. There are, however, some reasons for caution in interpreting the results in this way. Firstly, as previously noted, there is evidence of collinearity between some containment policies -- notably school closures, workplace closures and stayat-home requirements -- which suggests particular caution in interpreting the estimated coefficients relating to these policies. Secondly, while most containment policies have, at some level of stringency, an effect on $\mathrm{R}$ and mobility which is statistically significantly different from zero, the difference between policies, particularly as regards the effect on $R$, is often not statistically significant.

49. Bearing these limitations in mind, the containment policies which appear the most obvious candidates for extension are:

- Restrictions on international travel, including obligations to quarantine all arrivals from selected countries, would reduce $\mathrm{R}$ significantly and may have only a small effect on mobility (although this may be because the mobility measure does not capture international mobility accurately).

- Restrictions on gatherings has a substantial effect on reducing $R$, whereas the cancellation of public events (which would seem to be inevitably linked) has a relatively small effect on mobility. Such policies may be particularly effective because such large public gatherings may otherwise represent a risk of being so-called 'superspreader' events.

50. In both cases, such measures might have serious adverse effects on particular sectors of the economy (notably, entertainment and travel) which might warrant some targeted support. However, their effect on wider economic activity may be more limited than that of other containment measures.

51. The estimation results also suggest that resort to the most stringent form of workplace closures, school closures and stay-at home requirements at the national level are likely to have a relatively large adverse effect on mobility (and by extension economic activity) relative to the reduction in $\mathrm{R}$ achieved. 


\section{References}

Acemoglu, D. et al. (2020), "Optimal Targeted Lockdowns in a multi-group SIR model", NBER Working Paper, No. 27102, May.

Ahammer, A., M. Halla and M. Lackner (2020), "Mass Gathering Contributed to Early COVID-19 Spread: Evidence from US Sports”, Covid Economics, No. 30, 19 June.

Aleta et al. (2020), "Modelling the impact of testing, contact tracing and household quarantine on second waves of Covid-19", Nature Human Behaviour, 5 August.

Anderson, R.M., H. Heesterbeek, D. Klinkenberg and T.D. Hollingsworth (2020), "How will country-based mitigation measures influence the course of the COVID-19 epidemic?", The Lancet, Vol. 395, No. 10228, pp. 931-934.

Atkeson, A. (2020), "What will be the Economic Impact of COVID-19 in the US? Estimate of Disease Scenario", NBER Working Paper, No. 26867, March.

Bai, N. (2020), "Still confused about masks? Here's the science behind how face masks prevent coronavirus", University of California San Francisco.

Bettencourt L.M.A. and R.M. Ribeiro (2008), "Real Time Bayesian Estimation of the Epidemic Potential of Emerging Infectious Diseases", PLOS ONE, Vol. 3, No. 5.

Bulman, T. and S. Koirala (2020), "The OECD COVID-19 Policy Tracker: What are governments doing to deal with the COVID-19 pandemic?", OECD Ecoscope blog post, 15 May.

Chen, M.K., J.A. Chevalier and E.F. Long (2020), "Nursing Home Staff Networks and Covid-19", NBER Working Paper, No. 27608, July.

Chu et al. (2020), "Physical distancing, face masks and eye protection to prevent person-to-person transmission of SARS-COV-2 and Covid-19: A systematic review and meta-analysis", The Lancet, 395, 1973-1987.

Conyon, M.J., L. He and S. Thomsen (2020), "Lockdowns and Covid-19 Deaths in Scandinavia", Covid Economics, No. 26, 5 June.

Davies, N.G., A.J. Kucharski, R.M. Eggo, A. Gimma and W.J. Edmunds (2020), "Effects of nonpharmaceutical interventions on Covid-19 cases, death and demand for hospital services in the UK: A modelling study", The Lancet Public Health, Vol. 5, No. 7, 2 June.

Deb, P., D. Furceri, J. D. Ostry and N. Tawk (2020a), "The Effect of Containment Measures on the Covid19 Pandemic", Covid Economics, No. 19, 18 May.

ECDC (2020b), 'Surveillance of Covid-19 at long-term care facilities in the EU/EEA', European Centre for Disease Prevention and Control Technical Report, 19 May.

ECDC (2020c), "Contact tracing for COVID-19: current evidence, options for scale-up and an assessment of resources needed", European Centre for Disease Prevention and Control, May 5,

Ferguson et al. (2020), "Impact of non-pharmaceutical interventions (NPIs) to reduce COVID-19 mortality and healthcare demand", Imperial College COVID-19 Response Team, London. 
Euronews (2020), "Slovakia attempts to test entire adult population for coronavirus", 3 November.

Gandal, N., M. Yonas, M. Feldman, A. Pauzner and A. Tabbach (2020), "Long-term care facilities as a risk factor in death from Covid-19, 13 July

Goolsbee, A. and C. Syverson (2020), "Fear, Lockdown, and Diversion: Comparing Drivers of Pandemic Economic Decline 2020", BFI Working Paper, No. 2020-80, Becker-Friedman Institute for Economics at the University of Chicago.

Grassly, N.C. et al., (2020), "Comparison of molecular testing strategies for Covid-19 control: A mathematical modelling study", August 18.

Hale, T. et al. (2020), "Oxford COVID-19 Government Response Tracker", Blavatnik School of Government, Oxford University.

Hatzius, J., D. Struyven and I. Rosenberg (2020), "Face Masks and GDP", Goldman Sachs Global Economics Analyst, 29 June.

$\mathrm{He}$, X. et al. (2020), "Temporal dynamics in viral shedding and transmissibility of Covid-19", Nature Medicine, 26, 672-675.

Hellewell, J. et al. (2020), "Feasibility of controlling COVID-19 outbreaks by isolation of cases and contacts", The Lancet Global Health, Vol. 8/4, pp. e488-e496.

Hornstein, A. (2020), "Social Distancing, Quarantine, Contact Tracing and Testing: Implications of an Augmented SEIR Model”, Covid Economics, No. 18, 15 May.

Hubert, O. (2020), "Spacial Distancing: Air Traffic, Covid-19 Propagation and the Cost of Efficiency of Air Travel Restrictions", Covid Economics, Issue No. 24, 1 June.

Hunter, P.R., F.J. Colón-González, J. Brainard and S. Rushton (2020), "Impact of non-pharmaceutical interventions against COVID-19 in Europe: a quasi-experimental study", mimeo.

Keita, S. (2020), "Air Passenger Mobility, Travel Restrictions and the Transmission of the Covid-19 Pandemic between Countries", Covid Economics, No. 9, 24 April.

Koshkouei, M., L. Abel and C. Pilbeam (2020), "How can pandemic spreads be contained in care homes?", University of Oxford.

Lau, M. et al. (2020), Characterizing super-spreading events and age-specific infectiousness of SARSCoV-2 in Georgia, medRxiv preprint, 20 August.

Leffler, G.T., E. Ing, J.D. Lykins, M.C. Hogan, C.A. McKeown and A. Grzybowski (2020), "Association of country-wide coronavirus mortality with demographics, testing, lockdowns, and public wearing of masks", mimeo.

Liang, L-L. et al. (2020), "Covid-19 mortality is negatively associated with test number and government effectiveness", Sci Rep 10, 12567 (2020).

Matrajt, L. and T. Leung (2020), "Evaluating the Effectiveness of Social Distancing Interventions to Delay or Flatten the Epidemic Curve of Coronavirus Disease", Emerging Infectious Diseases, Vol. 26, No. 8, August.

Mills, M. (2020), "Face masks and coverings for the general public: Behavioural knowledge, effectiveness of cloth coverings and public messaging", June 26, University of Oxford.

Mitze, T., R. Kosfeld, J. Rode and K. Wälde (2020), "Face Masks Considerably Reduce Covid-19 Cases in Germany: A Synthetic Control Method Approach", Covid Economics, No. 27, 9 June.

New York Times (2020a), "More than $40 \%$ of US coronavirus deaths are linked to nursing homes", 13 August. 
New York Times (2020b), "A rapid virus test falters in people without symptoms, study finds", 3 November. OECD (2020a), "Testing for COVID-19: A way to lift confinement restrictions" (accessed on 26 June).

OECD (2020b), "Excess mortality: measuring the direct and indirect impact of Covid-19", ELS/SDD Policy Brief, forthcoming.

Panovska-Griffiths et al., (2020), "Determining the optimal strategy for reopening schools, the impact of test and trace interventions, and the risk of occurrence of a second Covid-19 epidemic wave in the UK: A modelling study", The Lancet Child and Adolescent Health, 3 August.

Oke, J. and C Heneghan (2020), Global Covid-19 Case Fatality Rates (updated 9 June 2020), Centre for Evidence-Based Medicine at Oxford University.

Raina et al. (2020), "Human coronavirus data from four clinical trials of masks and respirators', International Journal of Infectious Diseases", 96, 631-633. September.

Salje, H. et al. (2020), "Estimating the burden of SARS-CoV-2 in France", Science, 13 May.

Schünemann, H. et al. (2020), "Use of facemasks during the CODIV-19 pandemic", The Lancet, 3 August.

Stock, J.H. (2020), "Data Gaps and the Policy Response to the Novel Coronavirus", NBER Working Paper, No. 26902, March.

Systrom, K. (2020), "Estimating COVID-19's Rt in Real-Time", IPython Notebook.

Taipale, J., Romer P. and S. Linnarsson (2020), "Population-scale testing can suppress the spread of COVID-19", medRxiv.

Weber, E. (2020), “Which Measures Flattened the Curve in Germany?”, Covid Economics, No. 24, 1 June. 


\section{Annex A. Estimation of effective reproduction number (R)}

The estimation of effective reproduction numbers relies on code developed by Systrom (2020), who extends the static Bayesian approach of Bettencourt and Ribeiro (2008) to estimate a time-varying $R_{t}$ for US states. The code is adapted slightly to apply it to countries instead of US states and to combine information from both confirmed cases and deaths.

The basic idea is to estimate $R_{t}$ as a function of how many new cases appear each day using Bayes' Theorem. New information from each day's case count is used to adjust expectations of what $R_{t}$ is, getting closer to the true value as more daily data become available.

Formally, the likelihood that the reproduction rate is $R_{t}$ given $k_{t}$ new cases on day $t, P\left(R_{t} \mid k_{t}\right)$, is:

$$
P\left(R_{t} \mid k_{t}\right)=\frac{P\left(k_{t} \mid R_{t}\right) \cdot P\left(R_{t}\right)}{P\left(k_{t}\right)}
$$

where $P\left(k_{t} \mid R_{t}\right)$ is the likelihood of seeing $k_{t}$ new cases on a given day given $R_{t}, P\left(R_{t}\right)$ is the prior belief about the value of $R_{t}$ without today's data and $P\left(k_{t}\right)$ is the probability of seeing this many cases in general. Obtaining the likelihood function $P\left(k_{t} \mid R_{t}\right)$ starts from the Poisson distribution for the probability of seeing $k_{t}$ new cases given an average arrival rate of new cases per day $(\lambda)$.

$$
P\left(k_{t} \mid \lambda\right)=\frac{\lambda^{k_{t}} e^{-\lambda}}{k_{t} !}
$$

The average arrival rate of new cases $(\lambda)$ relates to the effective reproduction number of an infectious disease in the following manner [see Bettencourt and Ribeiro (2008) for the derivation]:

$$
\lambda=k_{t-1} e^{\gamma\left(R_{t}-1\right)}
$$

where $\gamma$ is the reciprocal of the serial interval (i.e. the average number of days over which an infected person will contaminate others). Based on the epidemiological literature, a serial interval of seven days is assumed here (Anderson et al., 2020 and Salje et al., 2020). Given this assumption and an observation for cases on the previous day $\left(k_{t-1}\right)$, equation [3] can be substituted into equation [2] to obtain $P\left(k_{t} \mid R_{t}\right)$.

Except for the first day, where an independent prior is needed, the prior probability in equation [1], $P\left(R_{t}\right)$, is based on yesterday's posterior estimate, $P\left(R_{t-1}\right)$. The distribution of $R_{t}$ is assumed to be a Gaussian centred on $R_{t-1}$, so $P\left(R_{t} \mid R_{t-1}\right)=\mathcal{N}\left(R_{t-1}, \sigma\right)$, where $\sigma$ is a Gaussian noise parameter reflecting the belief that the value of $R_{t}$ likely changes from day to day. The higher $\sigma$, the more noise and the more the value of $R_{t}$ is expected to drift each day. Applying noise on noise iteratively means that there is a natural decay of distant posteriors.

The denominator of Bayes' rule in equation [1] is given by:

$$
P\left(k_{t}\right)=\sum_{R_{t}} P\left(k_{t} \mid R_{t}\right) \cdot P\left(R_{t}\right)
$$


It is the sum of the distribution of the numerator over all possible values of $R_{t}$ (assumed to theoretically range from 0 to 12). The value of $\sigma$ is chosen so as to maximise the likelihood of the observed data over all days $t$ and countries $i, P(k)$ :

$$
P(k)=\prod_{i, t} P\left(k_{i, t}\right)
$$

The procedure just described is applied separately to the worldwide daily dataset of new cases and new deaths. The idea is that both series contain some information about the progression of the epidemic and a better estimate can likely be obtained by combining this information. The series for daily new cases and new deaths are sourced from the European Centre for Disease Prevention and Control (ECDC). To reduce noise, the raw series are filtered using a 7-day centred rolling Gaussian window before estimation.

Nationally reported statistics on Covid- 19 cases and deaths can be affected by measurement errors, while differences in coding and reporting practices pose challenges when used for international comparisons. A possible alternative would be to look at all-cause (excess) mortality, which takes into account the possible underreporting of Covid-19 deaths (OECD, 2020b). However, this measure would reflect indirect effects, possibly positive (e.g. fewer road fatalities) or negative (e.g. increased mortality caused by foregone treatment).

As this study focuses on dynamics of the epidemic per se, excess mortality has not been considered as a convenient outcome variable. In addition, use of excess mortality would severely limit the estimation sample. Measures of excess deaths are currently available for only about 25 countries and only at the weekly or monthly frequency. For some countries, the data cover only selected major cities. Timeliness is another issue, in some countries the data are only made available with a lag of several weeks or even months. Working with the available excess deaths data at the weekly frequency would therefore mean shrinking the sample coverage substantially in both the country and time dimensions. Finally, to the extent that new infections have skewed toward younger age groups over the Northern Hemisphere summer, as reported by many countries, excess deaths may no longer be an accurate reflection of the number of new infections. The same issue applies to $R$ measures based on deaths. This is one reason why the $R$ measure used in the main analysis is an average of two $R$ independent estimates, one based on new cases and one based on new deaths.

When both the case-based and death-based $R_{t}$ can be calculated for a given country and day, the final $R_{t}$ estimate is an average of the two, except that a 10-day lead is applied to the death estimate to reflect the time window between case detection and death, consistent with Anderson et al. (2020) and Salje et al. (2020). The average time lag between infection and case detection is taken into account in the regression model itself by leading the $R_{t}$ series as dependent variable by 12 days relative to the right-hand side variables (e.g. government interventions). This means that the regressions assume an average of 12 days between infection and case confirmation, and 22 days ( 12 days +10 -day lead for deaths) between infection and death. For some countries and time periods where deaths are too low to calculate a death-based $R_{t}$, only the case-based estimate can be computed. In such cases, the final $R_{t}$ estimate is based on new cases only. This is also true of the most recent ten days of the sample period given the lead applied to the deaths estimate. 


\section{Annex B. Auxiliary regression results}

Table B.1. The drivers of the reproduction rate, OECD containment measures

\begin{tabular}{|c|c|c|c|}
\hline \multicolumn{3}{|c|}{$\begin{array}{l}\text { Oxford indicators } \\
\text { Baseline regression from Table } 5\end{array}$} & \multirow[t]{2}{*}{ OECD indicator } \\
\hline Dependent variable: $\ln (R)$ & & & \\
\hline Constant & $1.0947^{* *}$ & Constant & $0.9441^{* *}$ \\
\hline \multicolumn{4}{|l|}{ Containment policies } \\
\hline \multirow[t]{2}{*}{ Stay-at-home requirement (>=1) } & $-0.0536^{* *}$ & Stay-at-home requirement (=1) & $-0.0257^{* *}$ \\
\hline & & Stay-at-home requirement $(>=2)$ & $-0.1083^{\star *}$ \\
\hline Workplace closures (=1) & $-0.0614^{* *}$ & Workplace closures (>=1) & $-0.0263^{\star *}$ \\
\hline Workplace closures (>=2) & $-0.0767^{* *}$ & & \\
\hline School closures (>=2) & $-0.1773^{\star *}$ & School closures (>=2) & $-0.1346^{\star \star}$ \\
\hline Restrictions on gatherings (=2) & $-0.0393^{* *}$ & Restrictions on gatherings $(>=2)$ & $-0.2167^{* *}$ \\
\hline Restrictions on gatherings (>=3) & $-0.0883^{* *}$ & & \\
\hline International travel controls (>=1) & $-0.0629^{* *}$ & & \\
\hline \multicolumn{4}{|l|}{ Test and Trace policies } \\
\hline Test $=1$ or 2 , Trace $=1$ or 2 & $-0.1110^{* *}$ & & \\
\hline Test=3, Trace=1 & $-0.1364^{* *}$ & & \\
\hline Test=3, Trace $=2$ & $-0.2185^{\star *}$ & & \\
\hline $\begin{array}{l}\text { All Test \& T race combinations when deaths < } \\
10 \text { per million }\end{array}$ & $-0.0613^{* *}$ & & $-0.1279^{\star *}$ \\
\hline \multicolumn{4}{|l|}{ Policies protecting the elderly } \\
\hline Testing in care homes (=2) & $-0.0540^{* *}$ & Testing in care homes (=2) & $-0.0267^{\star}$ \\
\hline Restricting visits to care homes ( $>=1$ ) & $-0.1840^{\star *}$ & Restricting visits to care homes ( $>=1$ ) & $-0.1146^{\star *}$ \\
\hline Recommending elderly to stay at home & $-0.1022^{* *}$ & Recommending elderly to stay at home & $-0.1451^{* *}$ \\
\hline \multicolumn{4}{|l|}{ Other non-containment policies } \\
\hline Mandatory mask wearing indoors & $-0.1370^{* *}$ & Mandatory mask wearing indoors & $-0.1047^{* *}$ \\
\hline \multicolumn{4}{|l|}{ Death rates (per million population) } \\
\hline Daily national & $-0.0358^{* *}$ & Dailynational & $-0.0295^{\star *}$ \\
\hline Dailyglobal & $-0.3637^{\star *}$ & Daily global & $-0.3732^{* *}$ \\
\hline Total national & $-0.0007^{* *}$ & Total national & $-0.0006^{\star \star}$ \\
\hline Adjusted R-squared & 0.597 & & 0.642 \\
\hline Daily observations & 17624 & & 8984 \\
\hline Countries covered & 147 & & 74 \\
\hline Country fixed effects & Yes & & Yes \\
\hline
\end{tabular}

Note: As for Table 5.

Source: Authors' calculations. 
Table B.2. The drivers of mobility, OECD containment measures

Sample period: 1 January to 17 August 2020

Oxford indicators

Baseline regression from Table 6

OECD indicators

\begin{tabular}{|c|c|c|}
\hline \multicolumn{3}{|l|}{ Dependent variable: Mobility } \\
\hline Constant & $1.0241^{* *}$ & $0.9454^{* *}$ \\
\hline \multicolumn{3}{|l|}{ Containment policies } \\
\hline Stay-at-home requirement (=1) & $-0.0240^{* *}$ & $-0.0165^{\star *}$ \\
\hline Stay-at-home requirement (=2) & $-0.0668^{* *}$ & $-0.0406^{* *}$ \\
\hline Stay-at-home requirement (=3) & $-0.1252^{* *}$ & $-0.0749^{* *}$ \\
\hline Stay-at-home requirement (=4) & & $-0.0777^{* *}$ \\
\hline Stay-at-home requirement $(=5)$ & & $-0.1733^{* *}$ \\
\hline Workplace closures (=1) & $-0.0216^{\star *}$ & $0.0117^{* *}$ \\
\hline Workplace closures (=2) & $-0.0491^{* *}$ & $-0.0404^{* *}$ \\
\hline Workplace closures (=3) & $-0.1980^{\star *}$ & $-0.0531^{* *}$ \\
\hline Workplace closures (>=4) & & $-0.1120^{* *}$ \\
\hline School closures (=2) & $-0.0237^{* *}$ & $-0.0744^{* *}$ \\
\hline School closures (=3) & $-0.1098^{* *}$ & $-0.1413^{* *}$ \\
\hline School closures (=4) & & $-0.1450^{* *}$ \\
\hline School closures (=5) & & $-0.2188^{* *}$ \\
\hline Cancel public events (=2) & $-0.0369^{* *}$ & \\
\hline Cancel public events (=3) & & $-0.0562^{* *}$ \\
\hline Restrictions on internal movement (=2) & $-0.0220^{* *}$ & \\
\hline International travel controls $(=4)$ & $-0.0554^{* *}$ & \\
\hline Close public transport (=1) & $-0.0439^{* *}$ & \\
\hline Close public transport (=2) & $-0.0650^{* *}$ & \\
\hline \multicolumn{3}{|l|}{ Death rate (per million population) } \\
\hline Dailynational & $-0.0066^{* *}$ & $-0.0092^{* *}$ \\
\hline Adjusted R-squared & 0.759 & 0.633 \\
\hline Daily observations & 22741 & 12122 \\
\hline Countries covered & 128 & 68 \\
\hline Country fixed effects & Yes & Yes \\
\hline
\end{tabular}

Note: As for Table 6

Source: Authors' calculations. 
Table B.3. The drivers of the reproduction rate, advanced vs. emerging and developing countries

Sample period: 1 January to 17 August 2020

\begin{tabular}{|c|c|c|c|}
\hline & Baseline, Table 5 & Variant 1 & Variant 2 \\
\hline \multicolumn{4}{|l|}{ Dependent variable: $\ln (R)$} \\
\hline Constant & $1.0947^{\star *}$ & $1.0361^{\star \star}$ & $1.0312^{* *}$ \\
\hline \multicolumn{4}{|l|}{ Containment policies } \\
\hline Stay-at-home requirement $(>=1)$ & $-0.0536^{\star *}$ & $-0.0570^{\star *}$ & $-0.0150^{*}$ \\
\hline Stay-at-home requirement ( $>=1$ ) in advanced economies & & & $-0.1182^{* *}$ \\
\hline Workplace closures (=1) & $-0.0614^{* *}$ & $0.0249^{*}$ & 0.0122 \\
\hline Workplace closures $(=1)$ in advanced economies & & $-0.2134^{* *}$ & $-0.1765^{* *}$ \\
\hline Workplace closures (>=2) & $-0.0767^{* *}$ & 0.0125 & -0.0104 \\
\hline Workplace closures $(>=2)$ in advanced economies & & $-0.2474^{* *}$ & $-0.1762^{* *}$ \\
\hline School closures (>=2) & $-0.1773^{* *}$ & $-0.1636^{* *}$ & $-0.1580^{* *}$ \\
\hline Restrictions on gatherings (=2) & $-0.0393^{* *}$ & $-0.0463^{* *}$ & $-0.0461^{* *}$ \\
\hline Restrictions on gatherings (>=3) & $-0.0883^{* *}$ & $-0.0809^{* *}$ & $-0.0803^{* *}$ \\
\hline International travel controls (>=1) & $-0.0629^{* *}$ & $-0.0447^{* *}$ & $-0.0527^{* *}$ \\
\hline \multicolumn{4}{|l|}{ Test and Trace policies } \\
\hline Test $=1$ or 2, Trace $=1$ or 2 & $-0.1110^{* *}$ & $-0.1248^{* *}$ & $-0.1233^{\star *}$ \\
\hline Test=3, Trace $=1$ & $-0.1364^{* *}$ & $-0.1281^{\text {** }}$ & $-0.1240^{* *}$ \\
\hline Test $=3$, Trace $=2$ & $-0.2185^{\star *}$ & $-0.2330^{* *}$ & $-0.2317^{* *}$ \\
\hline All Test \& Trace combinations when deaths $<10$ per million & $-0.0613^{* *}$ & $-0.0552^{* *}$ & $-0.0550^{* *}$ \\
\hline \multicolumn{4}{|l|}{ Policies protecting the elderly } \\
\hline Testing in care homes $(=2)$ & $-0.0540^{* *}$ & $-0.0390^{\star *}$ & $-0.0438^{* *}$ \\
\hline Restricting visits to care homes (>=1) & $-0.1840^{* *}$ & $-0.1402^{* *}$ & $-0.1324^{* *}$ \\
\hline Recommending elderly to stay at home & $-0.1022^{* *}$ & $-0.0906^{* *}$ & $-0.0893^{* *}$ \\
\hline \multicolumn{4}{|l|}{ Other non-containment policies } \\
\hline Mandatory mask wearing indoors & $-0.1370^{\star *}$ & $-0.1501^{\star *}$ & $-0.1494^{* *}$ \\
\hline \multicolumn{4}{|l|}{ Death rates (per million population) } \\
\hline Daily national & $-0.0358^{* *}$ & $-0.0338^{* *}$ & $-0.0329^{* *}$ \\
\hline Daily global & $-0.3637^{* *}$ & $-0.3669^{* *}$ & $-0.3749^{* *}$ \\
\hline Total national & $-0.0007^{* *}$ & $-0.0006^{\star *}$ & $-0.0006^{* *}$ \\
\hline Adjusted R-squared & 0.597 & 0.598 & 0.6 \\
\hline Daily observations & 17624 & 17624 & 17624 \\
\hline Countries covered & 147 & 147 & 147 \\
\hline Country fixed effects & Yes & Yes & Yes \\
\hline
\end{tabular}

Note: As for Table 5.

Source: Authors' calculations. 


\section{6 | ECO/WKP(2020)41}

Table B.4. The drivers of mobility, advanced vs emerging and developing countries

Sample period: 1 January to 17 August 2020

\begin{tabular}{|c|c|c|c|}
\hline & Baseline, Table 6 & Variant 1 & Variant 2 \\
\hline \multicolumn{4}{|l|}{ Dependent variable: Mobility } \\
\hline Constant & $1.0241^{* *}$ & $1.0237^{* *}$ & $1.0236^{* *}$ \\
\hline \multicolumn{4}{|l|}{ Containment policies } \\
\hline Stay-at-home requirement (=1) & $-0.0240^{* *}$ & $-0.0228^{* *}$ & $-0.0207^{* *}$ \\
\hline Stay-at-home requirement (=2) & $-0.0668^{* *}$ & $-0.0668^{* *}$ & $-0.0664^{* *}$ \\
\hline Stay-at-home requirement $(=3)$ & $-0.1252^{* *}$ & $-0.1265^{* *}$ & $-0.1257^{\star *}$ \\
\hline Stay-at-home requirement $(>=1$ ) in advanced economies & & & -0.0060 \\
\hline Workplace closures (=1) & $-0.0216^{* *}$ & $-0.0233^{* *}$ & $-0.0239^{* *}$ \\
\hline Workplace closures (=2) & $-0.0491^{* *}$ & $-0.0416^{* *}$ & $-0.042^{* *}$ \\
\hline Workplace closures $(=3)$ & $-0.1980^{* *}$ & $-0.1896^{* *}$ & $-0.1903^{* *}$ \\
\hline Workplace closures $(=1)$ in advanced economies & & -0.0021 & -0.0001 \\
\hline Workplace closures $(>=2$ ) in advanced economies & & $-0.0306^{* *}$ & $-0.0286^{* *}$ \\
\hline School closures (=2) & $-0.0237^{* *}$ & $-0.0217^{* *}$ & $-0.0217^{* *}$ \\
\hline School closures (=3) & $-0.1098^{* *}$ & $-0.1085^{* *}$ & $-0.1086^{* *}$ \\
\hline Cancel public events (=2) & $-0.0369^{* *}$ & $-0.0358^{* *}$ & $-0.0358^{* *}$ \\
\hline Restrictions on internal movement (=2) & $-0.0220^{* *}$ & $-0.0226^{* *}$ & $-0.0229^{* *}$ \\
\hline International travel controls $(=4)$ & $-0.0554^{* *}$ & $-0.0572^{* *}$ & $-0.0571^{* *}$ \\
\hline Close public transport (=1) & $-0.0439 * *$ & $-0.0443^{* *}$ & $-0.0443^{* *}$ \\
\hline Close public transport (=2) & $-0.0650^{* *}$ & $-0.0688^{* *}$ & $-0.0684^{* *}$ \\
\hline \multicolumn{4}{|l|}{ Death rate (per million population) } \\
\hline Daily national & $-0.0066^{* *}$ & $-0.0060^{* *}$ & $-0.0061^{* *}$ \\
\hline Adjusted R-squared & 0.759 & 0.759 & 0.759 \\
\hline Daily observations & 22741 & 22741 & 22741 \\
\hline Countries covered & 128 & 128 & 128 \\
\hline Country fixed effects & Yes & Yes & Yes \\
\hline
\end{tabular}

Note: As for Table 6.

Source: Authors' calculations. 
Table B.5. The drivers of reproduction rate, isolating contact persons

Sample period: 1 January to 17 August 2020

\begin{tabular}{|c|c|c|c|c|}
\hline & Baseline, Table 5 & Variant 1 & Variant 2 & Variant 3 \\
\hline \multicolumn{5}{|l|}{ Dependent variable: $\ln (\mathrm{R})$} \\
\hline Constant & $1.0947^{* *}$ & $1.0553^{\star *}$ & $1.0545^{\star *}$ & $1.0447^{\star *}$ \\
\hline \multicolumn{5}{|l|}{ Containment policies } \\
\hline Stay-at-home requirement (>=1) & $-0.0536^{* *}$ & $-0.0501^{* *}$ & $-0.0506^{* *}$ & $-0.0486^{* *}$ \\
\hline Workplace closures (=1) & $-0.0614^{\star *}$ & $-0.0668^{* *}$ & $-0.0677^{\star *}$ & $-0.0767^{* *}$ \\
\hline Workplace closures (>=2) & $-0.0767^{\star *}$ & $-0.0736^{* *}$ & $-0.0742^{* *}$ & $-0.0778^{\star *}$ \\
\hline School closures (>=2) & $-0.1773^{\star *}$ & $-0.1615^{\star *}$ & $-0.1615^{\star *}$ & $-0.1615^{* *}$ \\
\hline Restrictions on gatherings (=2) & $-0.0393^{* *}$ & $-0.0397^{\star *}$ & $-0.0404^{* *}$ & $-0.0448^{* *}$ \\
\hline Restrictions on gatherings $(>=3$ ) & $-0.0883^{* *}$ & $-0.0844^{* *}$ & $-0.0849^{* *}$ & $-0.0860^{* *}$ \\
\hline International travel controls $(>=1)$ & $-0.0629^{* *}$ & $-0.0439^{* *}$ & $-0.0432^{* *}$ & $-0.0430^{* *}$ \\
\hline \multicolumn{5}{|l|}{ Test and Trace policies } \\
\hline Test $=1$ or 2, Trace $=1$ or 2 & $-0.1110^{* *}$ & $-0.0768^{* *}$ & $-0.0778^{* *}$ & $-0.0855^{* *}$ \\
\hline Test $=3$, Trace $=1$ & $-0.1364^{* *}$ & $-0.1015^{\star *}$ & $-0.1034^{* *}$ & $-0.0998^{\star *}$ \\
\hline Test $=3$, Trace $=2$ & $-0.2185^{* *}$ & $-0.1778^{* *}$ & $-0.1800^{* *}$ & $-0.1806^{* *}$ \\
\hline All Test \& Trace combinations when deaths $<10$ per million & $-0.0613^{* *}$ & $-0.0608^{* *}$ & $-0.0608^{* *}$ & $-0.0243^{\star *}$ \\
\hline Isolating contact persons & & $-0.2015^{\star \star}$ & $-0.2093^{* *}$ & $-0.1442^{\star *}$ \\
\hline Isolating the sick & & $-0.0186^{\star *}$ & & \\
\hline $\begin{array}{l}\text { All Test \& Trace combinations with isolation of contact } \\
\text { persons when deaths }<10 \text { per million }\end{array}$ & & & & $-0.1338^{\star *}$ \\
\hline \multicolumn{5}{|l|}{ Policies protecting the elderly } \\
\hline Testing in care homes (=2) & $-0.0540^{* *}$ & $-0.0588^{* *}$ & $-0.0558^{* *}$ & $-0.0543^{* *}$ \\
\hline Restricting visits to care homes (>=1) & $-0.1840^{* *}$ & $-0.1869^{* *}$ & $-0.1884^{* *}$ & $-0.1865^{\star *}$ \\
\hline Recommending elderly to stay at home & $-0.1022^{* *}$ & $-0.1010^{* *}$ & $-0.1025^{* *}$ & $-0.1022^{* *}$ \\
\hline \multicolumn{5}{|l|}{ Other non-containment policies } \\
\hline Mandatory mask wearing indoors & $-0.1370^{\star *}$ & $-0.1133^{* *}$ & $-0.1131^{* *}$ & $-0.1103^{\star *}$ \\
\hline \multicolumn{5}{|l|}{ Death rates (per million population) } \\
\hline Dailynational & $-0.0358^{* *}$ & $-0.0379^{* *}$ & $-0.0378^{* *}$ & $-0.0374^{* *}$ \\
\hline Daily global & $-0.3637^{\star *}$ & $-0.3358^{* *}$ & $-0.3373^{\star *}$ & $-0.3385^{\star *}$ \\
\hline Total national & $-0.0007^{* *}$ & $-0.0007^{* *}$ & $-0.0007^{* *}$ & $-0.0007^{* *}$ \\
\hline Adjusted R-squared & 0.597 & 0.599 & 0.599 & 0.603 \\
\hline Daily observations & 17624 & 17624 & 17624 & 17624 \\
\hline Countries covered & 147 & 147 & 147 & 147 \\
\hline Country fixed effects & Yes & Yes & Yes & Yes \\
\hline
\end{tabular}

Note: As for Table 5.

Source: Authors' calculations. 
Table B.6. The drivers of mobility: testing, isolating and mask wearing

Sample period: 1 January to 17 August 2020

\begin{tabular}{|c|c|c|c|c|c|}
\hline \multirow{2}{*}{ Dependent variable: Mobility } & Baseline, Table 6 & \multicolumn{2}{|c|}{ Test \& trace \& Isolate } & \multicolumn{2}{|c|}{ Mask wearing } \\
\hline & & & & & \\
\hline Constant & $1.0241^{* *}$ & $1.0214^{\star *}$ & $1.0075^{\star *}$ & $1.0184^{\star *}$ & $1.0177^{* *}$ \\
\hline \multicolumn{6}{|l|}{ Containment policies } \\
\hline Stay-at-home requirement $(=1)$ & $-0.0240^{* *}$ & $-0.0239^{* *}$ & $-0.0267^{* *}$ & $-0.0264^{* *}$ & $-0.0322^{* *}$ \\
\hline Stay-at-home requirement $(=2)$ & $-0.0668^{* *}$ & $-0.0659^{* *}$ & $-0.0688^{* *}$ & $-0.0665^{\star *}$ & $-0.0785^{\star *}$ \\
\hline Stay-at-home requirement $(=3)$ & $-0.1252^{* *}$ & $-0.1258^{* *}$ & $-0.1308^{* *}$ & $-0.1301^{* *}$ & $-0.1329^{* *}$ \\
\hline Workplace closures (=1) & $-0.0216^{* *}$ & $-0.0207^{* *}$ & $-0.0327^{* *}$ & $-0.034^{* *}$ & $-0.0342^{* *}$ \\
\hline Workplace closures (=2) & $-0.0491^{* *}$ & $-0.0506^{* *}$ & $-0.0604^{* *}$ & $-0.0587^{* *}$ & $-0.062^{* *}$ \\
\hline Workplace closures (=3) & $-0.1980^{* *}$ & $-0.1972^{* *}$ & $-0.2019^{* *}$ & $-0.2009^{* *}$ & $-0.1986^{* *}$ \\
\hline School closures (=2) & $-0.0237^{* *}$ & $-0.0261^{* *}$ & $-0.0315^{\star *}$ & $-0.0247^{* *}$ & $-0.0333^{* *}$ \\
\hline School closures (=3) & $-0.1098^{* *}$ & $-0.1116^{* *}$ & $-0.1104^{* *}$ & $-0.0992^{* *}$ & $-0.1025^{\star *}$ \\
\hline Cancel public events (=2) & $-0.0369^{* *}$ & $-0.0379^{* *}$ & $-0.0410^{* *}$ & $-0.0397^{* *}$ & $-0.0397^{* *}$ \\
\hline Restrictions on internal movement (=2) & $-0.0220^{* *}$ & $-0.0215^{* *}$ & $-0.0180^{* *}$ & $-0.0215^{\star *}$ & $-0.0222^{* *}$ \\
\hline International travel controls $(=4)$ & $-0.0554^{* *}$ & $-0.0554^{* *}$ & $-0.0576^{* *}$ & $-0.0537^{* *}$ & $-0.0504^{* *}$ \\
\hline Close public transport (=1) & $-0.0439^{* *}$ & $-0.0469 * *$ & $-0.0511^{* *}$ & $-0.0496^{\star *}$ & $-0.0441^{* *}$ \\
\hline Close public transport (=2) & $-0.0650^{* *}$ & $-0.0655^{\star *}$ & $-0.0703^{* *}$ & $-0.0646^{* *}$ & $-0.0632^{* *}$ \\
\hline Isolating contact persons & & $0.0322^{\star *}$ & $0.0221^{* *}$ & & \\
\hline Test $=1$ or 2, Trace $=1$ or 2 & & & $0.0276^{* *}$ & & \\
\hline Test $=3$, Trace $=1$ & & & $0.0430^{* *}$ & & \\
\hline Test $=3$, Trace $=2$ & & & $0.0732^{* *}$ & & \\
\hline Mandatory mask wearing indoors & & & & $0.0605^{* *}$ & \\
\hline Mandatory mask wearing in public trans & & & & & $0.0592^{* *}$ \\
\hline Mandatory mask wearing in shops & & & & & $0.0644^{* *}$ \\
\hline \multicolumn{6}{|l|}{ Death rate (per million population) } \\
\hline Daily national & $-0.0066^{* *}$ & $-0.0066^{* *}$ & $-0.0066^{* *}$ & $-0.0071^{* *}$ & $-0.0060^{* *}$ \\
\hline Adjusted R-squared & 0.759 & 0.758 & 0.763 & 0.762 & 0.766 \\
\hline Daily observations & 22741 & 22383 & 22190 & 22383 & 22249 \\
\hline Countries covered & 128 & 126 & 126 & 126 & 125 \\
\hline Country fixed effects & Yes & Yes & Yes & Yes & Yes \\
\hline
\end{tabular}

Note: As for Table 6.

Source: Authors' calculations. 